Eskişehir Osmangazi Üniversitesi İlahiyat Fakültesi Dergisi Journal of Eskişehir Osmangazi University Faculty of Theology ISSN: 2147-8171

\title{
Ebü’l-Kāsım Abdurrahman es-Sakalî (öl. 380/990 [?]) ve Tasavvuf Tarihindeki Yeri
}

\section{Abū al-Kāasim 'Abd al-Raḥmān al-Ṣaqalì (d. 380/990 [?]) and His Place in the History of Șūfism}

\section{Dr. Öğr. Üyesi Hac1 Bayram BAŞER}

Yalova Üniversitesi, İslami İlimler Fakültesi, Tasavvuf Anabilim Dalı

Yalova University, Faculty of Islamic Sciences, Departmant of Sufi Studies, Yalova, Turkey.

bayram.baser@yalova.edu.tr

(DD 0000-0001-7462-1174

\begin{tabular}{lcr}
\multicolumn{3}{c}{ Makale Bilgisi / Article Information } \\
Makale Türü / Article Type & Araştırma Makalesi / Research Article \\
Geliş Tarihi / Received & Kabul Tarihi / Accepted & Yayın Tarihi / Published \\
13 Aralık /December 2020 & 22 Şubat / February 2021 & 17 March / March 2021
\end{tabular}

\section{Attf Bilgisi / Cite as:}

Başer, Hacı Bayram. “Ebü'l-Kāsım Abdurrahman es-Sakalî (öl. 380/990 [?]) ve Tasavvuf Tarihindeki Yeri”, Eskişehir Osmangazi Üniversitesi İlahiyat Fakültesi Dergisi 8/1 (Mart 2021), 227-255. http://doi.org/1051702/esoguifd.840080.

Intihal / Plagiarism: Bu makale, en az iki hakem tarafından incelenmiş ve intihal içermediği teyit edilmiştir. / This article has been reviewed by least two referees and scanned via a plagiarism software.

Copyright @ Published by Eskişehir Osmangazi Üniversitesi, İlahiyat Fakültesi /Eskişehir Osmangazi University, Faculty of Theology Bütün hakları saklıdır. / All right reserved. https://dergipark.org.tr/tr/pub/esoguifd

CC BY-NC 4.0 This paper is licensed under a Creative Commons Attribution-NonCommercial License

Etik Beyanı / Ethical Statement: Bu çalışmanın hazırlanma sürecinde bilimsel ve etik ilkelere uyulduğu, yararlanılan tüm çalışmaların kaynakçada belirtildiği ve bu araştırmanın desteklenmesi için herhangi bir dış fon alınmadığı yazar tarafından beyan olunur / It is declared by the author that scientific and ethical principles have been followed while carrying out and writing this study; that all the sources used have been properly cited; that no external funding was received in support of the research. 


\section{Ebü'l-Kāsım Abdurrahman es-Sakalî (öl. 380/990 [?]) ve Tasavvuf Tarihindeki Yeri}

Öz • Bu makalede el-Envār fî 'ilmi'l-esrār ve makāmāti'l-ebrār ve ed-Delāle 'alellāh isimli eserlerin müellifi Ebü'lKāsım Abdurrahman es-Sakalî̀nin (öl. 380/990 [?]) biyografisi ortaya konulmaktadır. Sakalî, hicri dördüncü yüzyılda Kayrevân'da yetişmiş, Hicaz'a yaptığı seyahatte Sehl b. Abdillah et-Tüsterînnin talebeleriyle irtibat kurarak onun bir takipçisi olmuş ve bu çerçevede eserler kaleme almış Mâlikî bir mutasavvıftır. Dönemin ünlü Mâlikî âlimleri İbn Ebû Zeyd ve Ebü'l-Hasen el-Kābisî ile velâyet ve kerâmet konularında ihtilaf yaşamış ve bu ihtilaf İslam dünyasının farklı muhitlerine de etki etmiştir. Bununla birlikte klasik ve çağdaş kaynaklarda Sakalînnin kimliğine ve ilim çevresine ilişkin çok sayıda belirsizlik bulunmakta, bu da Sakalî hakkındaki çalışmaları zorlaştırmaktadır. Bu çerçevede makalede tasavvuf literatürü ve Mâlikî tabakāt literatürü disiplinler arası bir metotla mukayeseli bir şekilde incelenmiş, Sakalînnin nisbesinin nasıl okunması gerektiği soruşturulmuş, onun ilişkili olduğu âlimler ve sûfîler tespit edilmiştir. Dolayısıyla bu makalenin amacı, klasik ve çağdaş kaynaklardaki bilgileri bir araya getirerek Sakalî’nin biyografisiyle ilgili güncel bir anlatıya ulaşmak ve onun tasavvuf tarihindeki önemine dikkat çekmektir.

Anahtar Kelimeler: Tasavvuf, es-Sakalî, es-Sakallî, es-Sıkıllî, Sehl et-Tüsterî, İbn Ebû Zeyd, Velâyet, Kerâmet

\section{Abū al-Ḳāsim 'Abd al-Rahmān al-Ṣaqalī (d. 380/990 [?]) and His Place in the History of Șūfism}

Abstract \ In this article, the biography of Abū al-Kāsim 'Abd al-Rahmān al-Ṣaqalī (d. 380/990 [?]), who is the author of works, al-Anwār fi 'ilm al-asrār wa makāmāt al-abrār and al-Dalāla 'alā Allāh, is presented. al-Ṣaqalī grew up in al-Kayrawān in the $4^{\text {th }}$ century AH and during a journey to the Hijāz he made contact with the students of Sahl al-Tustarī and became one of his followers. He was a Mālikī Șūfī who had written books within this framework. He had a dispute over the issue of sainthood (wilāya) and miracles (karāmāt) with Ibn Abī Zayd and Abū al-Hasan alQābisī, who were the famous Mālikī scholars of the time and this dispute also had an influence on various circles of the Islamic world. However, in both the classical and the contemporary sources there is so much ambiguity regarding the identity of al-Ṣaqali and his scholarly entourage which makes it hard to study him. Within this scope in this article, the șūfi literature and Mālikī țabaqāt literature are examined comparatively with an interdisciplinary method, it is inquired how his nisba should be read and scholars and șūfīs connected with him are identified. Therefore the aim of this article is to reach a contemporary narrative about the biography of al-Ṣaqali by combining the information about him found in classical and modern sources and draw attention to his significance in the history of Șūfism.

Keywords: Ṣūfism, al-Ṣaqalī, al-Ṣaqallī, al-Ṣikillī, Sahl al-Tustarī, Ibn Abī Zayd, Wilāya, Karāmāt.

\section{Giriş}

Tasavvufun teşekkül dönemine ilişkin bildiklerimiz, büyük ölçüde, birçoğu hicrî üçüncü ve beşinci asırlar arasında kaleme alınmış ve tasavvufun temel konularını, tarihsel gelişimini ya da tartışmalı meselelerini savunmacı bir yaklaşımla ele alan eserlere dayanmaktadır. Hâris elMuhâsibî̀den (öl. 243/857) başlayarak Ebû Nasr es-Serrâc (öl. 378/988), Ebû Bekir el-Kelâbâzî (öl. 380/990), Ebû Tâlib el-Mekkî (öl. 386/996), Ebû Abdirrahman es-Sülemî (öl. 412/1021), Ebû Nu'aym el-İsfahânî (öl. 430/1038), Abdülkerîm el-Kuşeyrî (öl. 465/1072), Ali b. Osman el-Hücvîrî (öl. 465/1072) ve Hâce Abdullah el-Ensârî el-Herevî (öl. 481/1089) gibi müelliflerin eserleri, tasavvufun İslâm toplumunda hangi sâiklerle yaygınlaşmaya başladığı ve zaman içinde bir "ahlâk hareketi” 
görünümünden sıyrılarak nasıl bir "dinîilim” hüviyeti kazandığı sorunuyla ilgili genel bir çerçeveye ulaşabilmemizi sağlamaktadır. Ancak bu eserlerden elde edilen bakış açısı, daha çok Irak ve Horasan havzasındaki gelişmelere odaklanmamızı gerektirir. Bu bakımdan İslâm dünyasının diğer bölgelerinde, özellikle de Kuzey Afrika ve Endülüs civarında tasavvufun gelişimi hakkında bildiklerimiz son derece kısıtlıdır. Kadir Özköse'nin Mağrip ve Endülüs civarındaki tasavvuf tarihine odaklanan çalışmaları günümüz tasavvuf araştırmaları bakımından önemli bir boşluğu doldurmaktadır. ${ }^{1}$ Ancak bu çalışmalarda hicrî beşinci/miladî on birinci asırdan önce tasavvufun genelde Kuzey Afrika, özelde ise Kayrevân'da gelişimi hususunda çok az bilgi ve değerlendirme bulunur. Bu sorunu aşmanın yollarından biri, söz konusu dönemde ve bölgede etkin olmuş isimleri gün yüzüne çıkarmak olabilir. Bu bağlamda karşımıza çıkan en önemli isim Ebü'l-Kāsım Abdurrahman es-Sakalî’dir (öl. 380/990 [?]).

Sakalî, Sicilya'da doğmuş ve Kayrevân'da Mâlikî âlimlerin elinde yetişmiş bir mutasavvıftır. Dinî tahsilinin ardından Mekke, Medine ve Mısır'a yaptığı yolculuklar esnasında Bağdat ve Basra merkezinde gelişen tasavvuf anlayışlarıyla tanışmış, Sehl b. Abdillah et-Tüsterî̀nin (öl. 283/896) takipçileriyle irtibat kurmuş ve onlardan kazandığı birikimle çeşitli eserler telif etmiştir. Aynı zamanda kendisi, Kayrevân'daki Mâlikî âlimlerle velâyet ve kerâmet meseleleri hakkında ihtilaf yaşamıştır. Nitekim aralarındaki tartışmalar İslâm dünyasının farklı bölgelerinden âlimleri de etkilemiş ve bu çerçevede bir literatür oluşmasına da zemin hazırlamıştır.

Bu etkinliğine rağmen Sakalî hakkındaki en önemli sorun, biyografisindeki belirsizliklerdir. İhsan Abbâs, Gerhard Böwering, Muhammed Kemal Ca'fer gibi çağdaş araştırmacılar, aşağıda atıf yapacağımız çalışmalarında Sakalî ismine dikkat çekmişler, Hasan Hanefî de Sakalî̀nin günümüze ulaşan ve yayınlanan el-Envār'ı bağlamında onu tasavvufun gelişim sürecinde "ahlâk" alanında etkili olan bir müellif olarak konumlandırmıştır. ${ }^{2}$ Ancak hem klasik hem de çağdaş kaynaklarda Sakalînnin biyografisine ilişkin çok sayıda belirsizlik ve hatalı bilgi tercihleri bulunmakta, bu da Sakalî ile ilgili çalışmaları güçleştirmektedir. Bunun yanında Türkçe'de Sakalî hakkında müstakil hiçbir çalışma bulunmamaktadır. Dolayısıyla bu makalenin amacı, Sakalînnin biyografisiyle ilgili belirsizlikleri çözmeye çalışarak onun hayat hikâyesine dair güncel ve bütüncül bir anlatıya ulaşmak ve Sakalî̀nin tasavvuf tarihindeki yerine dikkat çekmektir.

Irak ve Horasan havzasındaki tasavvuf tarihine odaklanan klasik tasavvuf eserleri Sakalî’nin kimliğine dair neredeyse hiçbir bilgi barındırmaz. Bu durum disiplinler arası bir metotla diğer literatür türlerine eğilmemizi gerektirir. Bu bakımdan Sakalînnin biyografisine ilişkin bilgileri, Sehl'e ve kendisine nispet edilen birtakım yazma eserlerdeki rivayet ağlarından ve Mâlikî tabakāt yazıcılarının verdiği bilgilerden hareketle ortaya çıkarmaya gayret edeceğiz. Bu çerçevede öncelikle Sakalî’nin nisbesi hakkındaki belirsizlikleri soruşturacağız. Ardından kronolojik bir takiple klasik ve

\footnotetext{
${ }^{1}$ Bu konuda bk. Kadir Özköse, Afrika Tasavvuf Araştırmaları (Trabzon: Kalem Yayınevi, 2019); a.mlf., Endülüs ve Afrika'da Tasavvuf Kültürü (Trabzon: Kalem Yayınevi, 2019).

${ }^{2}$ Hasan Hanefî, Mine'l-fenâ ile'l-bekā (Beyrut: Dâru'l-Medâri'l-İslâmî, 2009), 1/72-79.
} 
çağdaş kaynaklarda Sakalî hakkındaki bilgileri mukayeseli bir şekilde tespit edeceğiz. Son olarak onun biyografisine dair güncel bir anlatı ortaya koymaya çalışacağız.

\section{Sakalînnin Nisbesi Hakkındaki Belirsizlikler}

Ebü'l-Kāsım Abdurrahman b. Muhammed hakkındaki belirsizliklerden ilki, nisbesinin nasıl okunması gerektiğiyle ilgilidir. Güncel Arapçada Sicilya "Sıkılliye" şeklinde ifade edilse bile, "Sicilyalı" anlamına gelen nisbenin okunuşu hususunda klasik ve çağdaş kaynaklarda bir birliktelik bulunmamaktadır.

Görebildiğimiz kadarıyla Sakalî̀nin ismine muhtemelen ilk kez rastlanan eser Ebû Bekir Abdullah b. Muhammed el-Mâlikînnin (öl. 494/1100 [?])3 Kuzey Afrikalı âlimleri anlattığı Riyâżü’nnüfûs isimli tabakātıdır. Ancak sadece bir "râvî" olarak göründüğü bu eserde ismi "Abdurrahman b. Muhammed" olarak geçer ve nisbesinin okunuşuyla ilgili bilgi verilmez. Aşağıda değineceğimiz üzere, en erken istinsah tarihi hicrî yedinci yüzyıl olan ${ }^{5}$ ve Ebü'l-Kāsım Abdurrahman'ın ismine rastlanan birtakım yazma nüshalarda da bu nisbe ya harekesiz olarak yazılmış ya da hiç yazılmamıştır. ${ }^{7}$ Sakalî hakkındaki -ulaşabildiğimiz kadarıyla- en geniş biyografik bilgilerin yer aldığı en erken tarihli eser olan Abdurrahman b. Muhammed ed-Debbâğ'ın (öl. 699/1300) Méâlimü'l-îmân fî márifeti ehli'l-Kayrevân'inda da söz konusu nisbenin hareke zaptı belirsiz olduğu gibi, bu nisbeyle anılan başka isimlerde de herhangi bir izah yer almaz. ${ }^{8}$

Bu durumda klasik literatür, sorunun çözümü açısından önemli hale gelir. Bu noktada öncelikle Sicilya'nın fethinin tam olarak tamamlandığı hicrî üçüncü asrın sonları ile beşinci asır arasındaki ensab literatürü dikkate alınabilir. Bu bakımdan öne çıkan iki ensab yazarı akla gelir: Abdülganî el-Ezdî (öl. 409/1018) ve ondan hadis icazeti alan Nemerî (öl. 463/1071). Fakat her ikisi de bu nisbe hakkında hiçbir bilgi vermez. ${ }^{9}$ Yaklaşık bir asır sonra, ensab literatüründe önemli bir yeri

\footnotetext{
${ }^{3}$ Ebû Bekir el-Mâlikî̀nin ne zaman vefat ettiğiyle ilgili belirsizlik mevcuttur, fakat eserini neşre hazırlayan Beşîr Bekkûş’un yaptığı ayrıntılı araştırma onun hicrî beşinci asrın sonlarında vefat ettiğini göstermektedir. Ayrıntılı bilgi için bk. Beşîr Bekkûş, "Mukaddime”, Riyâżün-nüfûs, mlf. Ebû Bekir Abdullah b. Muhammed el-Mâlikî, 1/19-22 (Beyrut: Dâru'l-Garbi'l-İslâmî, 1414/1994).

${ }^{4}$ Ebû Bekir el-Mâlikî, Riyâzü̈n-nüfûs, 2/322, 384, 451, 503.

${ }^{5}$ Fuat Sezgin, Geschichte des arabischen Schrifttums (Leiden: Brill, 1967-2015), 1/647.

6 [تأليف الثيخ العارف أبي القاسم عبد الرحمان بن محمد الصقلى...] bk. Ebü'l-Kāsım Abdurrahman b. Muhammed es-Sakalî, Kitâbu'şŞerh ve'l-beyân li mâ eşkele min kelâmî Sehl (İstanbul: Süleymaniye Kütüphanesi, Esad Efendi, 1623) 1b.

7 [ اثثنا أبو القسم عبد الرحمن بن محمد بن عبدالله الز اهد بمدينة القيروان...] bk. Sehl b. Abdillah et-Tüsterî, Kitâbu'l-Mu'âraża ve'r-red 'alâ

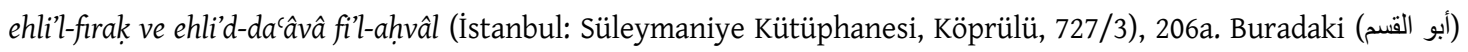
muhtemelen hatalı bir yazımdır.

${ }^{8}$ Abdurrahman b. Muhammed ed-Debbâğ - İbn Nâcî, Me âlimü'l-îmân fî márifeti ehli'l-Kayrevân, nşr. Muhammed elAhmedî Ebü'n-Nûr - Muhammed Mâdûr (Kahire: Mektebetü'l-Hancî - Tunis: Mektebetü'l-Atîka, 1968-1978), 3/144146.

${ }^{9}$ bk. Abdülganî el-Ezdî, el-Mü’telif ve'l-muhtelif fî esmâ’'i'r-ricâl, thk. Müsnâ Hamîd eş-Şemerî - Kays Abdu İsmail etTemîmî (Beyrut: Dâru'l-Garbi'l-İslâmî, 1428/2007); İbn Abdülber en-Nemerî, el-Kașd ve'l-ümem fi't-ta'rîf bi-uṣ̂uli ensâbi'l-'Arab; el-İnbâh 'alâ kabâ’ili'r-ruvât (Kahire: Mektebetü'l-Kudsî, ts.).
} 
hâiz ve aslen Horasanlı olan el-Ensâb müellifi Ebû Sa'd Abdülkerîm es-Sem‘ânî (öl. 562/1166) bu nisbenin الصَقَّليّ (es-Sakalî) şeklinde okunduğunu, bu okunuşu zabtlı bir şekilde Ömer b. Abdülkerîm

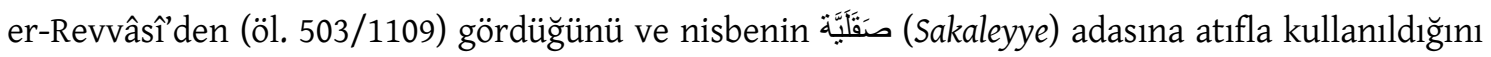
belirtir. ${ }^{10}$ Sem ‘ânînin bir muhaddis olan Revvâsî'den Tûs'taki evinde Sahihayn dersleri aldığ1 bilinmektedir. ${ }^{11}$ Dolayısıyla nisbeyle ilgili bilgisinin bu birlikteliğe dayandığı düşünülebilir. Horasan ve Sicilya arasındaki coğrafi uzaklık hesaba katıldığında Sem‘ânî’nin okuyuşunda hata olabileceği göz önünde tutulabilir, fakat onun zaptını destekleyen bilgilere kendisinden bir asır sonra da

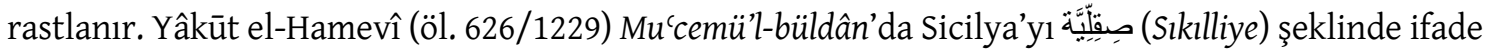

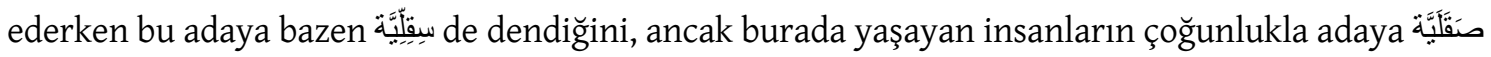
(Sakaleyye) dediklerini belirtir. ${ }^{12}$ İbn Hallikân (öl. 681/1282), ünlü şair İbn Hamdîs’i (öl. 527/1133) anlattığı kısımda onun Sicilya'ya özlemini dile getirdiği bir şiirini aktarırken ilgili kelime (Sakalliye) şeklinde belirtilir. Ayrıca nisbenin okunuşu hakkında hareke zaptını الصَفَّلِّئِ (es-Sakallî) olarak açıkça ifade eder..$^{13}$ Son olarak Fîrûzâbâdî (öl. 817/1415) ise Sicilya'ya (Sılkılliye) şeklinde $\mathrm{J}$ harfi şeddeli, harfi şeddesiz şekilde yer verir. ${ }^{14}$

Bütün bunlar arasında Sem‘ânî’nin aktarımı en azından, İslâm dünyasının doğusunda bile nisbenin hicrî beşinci asrın sonunda muhtemelen, hicrî altıncı asrın başında ise kesinlikle "Sakalî" şeklindeki okunduğunu gösterir. Yâkūt el-Hamevî ve İbn Hallikân'ın aktarımları ise ص ve ve harflerinin fethalı okunuşunun kesin olarak yanlış olmadığına ve nisbenin en azından hicrî altıncı asırda "es-Sakallî" şeklinde de okunabildiğine işaret etmektedir. O halde hicrî altıncı ve dokuzuncu asırdaki kaynaklar, söz konusu nisbenin "es-Sakalî”, "es-Sakallî” veya "es-Sıkıllî” şeklinde üç tür okunuşu bulunduğunu göstermekte; ancak bunlardan en erken tarihli izaha dayanan okunuşunun "es-Sakalî" olduğu ortaya çıkmaktadır.

10 ] bk. [الصَقَليّ: بفتح الصاد المهملة و القاف وفي آخر ها اللام. هكذا رأيت بخط عمر الرَّوَاسي مقيدا مضبوطا بفتح الصاد المهملة والقاف وفي آخر ها اللام. Abdülkerîm b. Muhammed es-Sem‘ânî, el-Ensâb, nşr. Abdullah Ömer el-Bârûdî (Beyrut: Dâru'l-Cinân, 1408/1988), $3 / 549$.

${ }^{11}$ Jonathan Brown, The Canonization of al-Bukhārī and Muslim: The Formation and Function of the Sunnī Hadìth Canon (Leiden, Boston: Brill, 2007), 356.

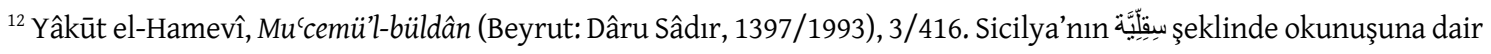
bulabildiğim tek örnek, ünlü coğrafyac1 İbn Hurdâzbih'e (öl. 300/912-13) aittir. Yâkūt'un İbn Hurdâzbih'in 272/885'te tamamladığı bu eserini gördüğü ve yararlandığı bilinmektedir, dolayısılla nisbenin bu şekildeki okunuşuyla ilgili kaynaklarından biri olabilir. bk. İbn Hurdâzbih, Kitâbü'l-Mesâlik ve'l-memâlik, nşr. Michael Jan de Goeje (Leiden: Brill, 1889), 91, 112, 155, 156, 231.

${ }^{13}$ İbn Hallikân, Vefeyâtü'l-a'yân ve enbâ'ü ebnẩ' 'z-zamân, nşr. İhsan Abbas (Beyrut: Dâru Sâdır, 1968-1972), 3/213-215.

${ }^{14}$ Fîrûzâbâdî, el-Kāmûuül-muhît (Beyrut: Müessesetü’r-Risâle, 1426/2005), "S1kılliye”, 1022; Mütercim Âsım Efendi, elOkyânûsü'l-basît fi tercemeti'l-Kāmûsi'l-muhît: Kâmûs Tercümesi, nşr. Mustafa Koç - Eyyüp Tanrıverdi (İstanbul: Türkiye Yazma Eserler Kurumu Başkanlı̆̆ı, 2013), "Sııilliyet”, 5/4592. Steingass (öl. 1903) bütün bunlardan farklılaşan bir okuyuş örneği olarak Sıklliyye ile birlikte Sıkliye okunuşuna da yer verir. bk. Francis Joseph Steingass, Persian-English Dictionary (London: Routledge \& Kegan Paul, 1963), “Sikilliyet”, 790. 
Ebü'l-Kāsım Abdurrahman'a değinen çağdaş araştırmalarda nisbenin belirsiz bırakılması ya da her üç okunuşunun da tercih edilmesi, bu şahıs hakkındaki araştırmaları güçleştiren bir handikaptır. Bağdatlı İsmail Paşa (öl. 1920), ${ }^{15}$ Muhammed Mahlûf (öl. 1941) ${ }^{16}$ ve Kehhâle'nin (öl. 1987) ${ }^{17}$ eserlerinde nisbe belirsiz olarak yer alır. Sakalî hakkında uzunca değerlendirme yapmasına rağmen Muhammed Kemal Ca'fer nisbenin okunuşunu belirtmez, ancak Yâkūt'a atıf yapmakla yetinir. ${ }^{18}$ Bu nisbe Ziriklî̀nin (öl. 1976) el-A 'lâm'inda “es-Sıkıllî”" olarak geçerken, ${ }^{19}$ Sakalî’nin el-Envār ve ed-Delāle 'alellāh eserlerini yayına hazırlayan Ahmed Ferîd el-Mezîdî, yazarın biyografisi hakkında Ziriklî ve Kehhâle gibi müelliflere atıf yapmakla birlikte, eserlerin kapağında J ve صarflerinin şeddeli belirtilmesinden başka hiçbir tercihte bulunmaz. ${ }^{20}$ Louis Massignon (öl. 1962) bazı eserlerinde nisbenin "es-Sakallî”" şeklindeki okunuşunu tercih ederken ${ }^{21}$ bir başka eserinde nisbeyi “es-Sakalî” şeklinde yazar. ${ }^{22}$ Benzer bir durum John Renard'in İbn Abbâd er-Rundî’nin (öl. 792/1390) mektuplarını çevirdiği çalışmasında da gözlenir. ${ }^{23}$ Bütün bunlara mukabil nisbenin "es-Sakalî" şeklindeki okunuşu, çağdaş araştırmacılar arasında daha fazla kabul görmüş görünmektedir. Massignon'dan başka Brockelmann ${ }^{24}$ ve Böwering, ${ }^{25}$ Sem'ânî'nin usûlünü dikkate aldıklarını

\footnotetext{
${ }^{15}$ Bağdatlı İsmail Paşa, Hediyyetü'l-cârifîn, esmâ'ü'l-müellifîn ve âsârü’l-musannifîn, nşr. Kilisli Rifat Bilge - İbnülemin Mahmûd Kemal İnal (İstanbul: Milli Eğitim Basımevi: 1951), 1/514.

${ }^{16}$ Muhammed Mahlûf, Şeceretü'n-nûri'z-zekiyye fị țabakāti'l-Mâlikiyye, thk. Abdülmecîd Hayâlî (Beyrut: Dâru'l-Kütübi'lİlmiyye, 1424/2003), 1/146.

${ }^{17}$ Ömer Rizâ Kehhâle, Mu'cemü'l-mü’ellifin (Beyrut: Mektebetü'l-Müsennâ, 1957), 5/181; a.mlf., Mu'cemü'l-mü’ellifin (Beyrut: Müessesetü'r-Risâle, 1993), 2/115.

${ }^{18}$ Muhammed Kemal İbrâhim Ca'fer, "Temhîd ve Dirâse", el-Mu'âraża ve'r-red 'alâ ehli'l-firak ve ehli'd-da'âvâ fi'l-aḥvâl, mlf. Sehl b. Abdillah et-Tüsterî, 51-62 (Kahire: Dâru'l-İnsân, 1980).

${ }^{19}$ Hayreddin ez-Ziriklî, el-A lâm: Kāmûuü terâcim, nşr. Züheyr Fethullah (Beyrut: Dâru'l-İlm li'l-Melâyîn, 2002), “esSikıllı̂”, 3/325.

${ }^{20}$ Bk. Ebü'l-Kāsım İmâdüddîn Abdurrahman b. Muhammed el-Bekrî es-Sakalî, el-Envār fì 'ilmi'l-esrār ve makāmāti'lebrār, thk. Ahmed Ferîd el-Mezîdî (Beyrut: Dâru'l-Kütübi'l-i̇lmiyye, 1421/2000); a.mlf., ed-Delāle 'alellāh, thk. Ahmed Ferîd el-Mezîdî (Beyrut: Dâru'l-Kütübi'l-i̇lmiyye, 1422/2001).

${ }^{21}$ Louis Massignon, Essai sur les Origines de Lexique Technique de la Mystique Musulmane (Paris: Paul Geuthner, 1922), 264-265; a.mlf., Essay on the Origins of the Technical Language of Islamic Mysticism, çev. Benjamin Clark (Notre Dame, Indiana: University of Notre Dame Press, 1997), 199-200. Ayrıca bk. Florian Sobieroj, Ibn-Hafîf aš-Šìrāzī und seine Schrift zur Novizenerziehung (Kitāb al-iqtișād) (Beyrut: Franz Steiner Verlag, 1988), 137, 216; Hacı Bayram Başer, Şeriat ve Hakikat: Tasavvufun Teşekkül Süreci (İstanbul: Klasik Yayınları, 2017), 249.

${ }^{22}$ Louis Massignon, Kitâb al-Ṭawâsîn (Paris: Paul Geuthner, 1913), 195.

${ }^{23}$ John Renard, Ibn 'Abbād of Ronda: Letters on the Süfì Path (New York: Paulist Press, 1986), 11, 148-150, 219. Ayrıca bk. Alexander Knysh, Sufism: A New History of Islamic Mysticism (Princeton: Princeton University Press, 2017), 207, 368.

${ }^{24}$ Carl Brockelmann, Geschichte der arabischen Litteratur (Leiden: Brill, 1937-1949), Suppl. 1/333; a.mlf., History of the Arabic Written Tradition, çev. Joep Lameer (Leiden: Brill, 2016), Suppl. 1/336.

${ }^{25}$ Gerhard Böwering, The Mystical Vision Existence in Classical Islam: Qur'ānic Hermeneutics of the Șüfi Sahl At-Tustarī (d. 283/896) (Berlin: De Gruyter, 1980), 13-16.
} 
belirterek "es-Sakalî" şeklindeki okunuşu tercih etmişler, Fuat Sezgin, ${ }^{26}$ Benedikt Reinert ${ }^{27}$ ve Renard da nisbenin bu okunuşuna yer vermişlerdir. Bu nisbe zaman zaman "Sıkıllî" şeklinde de okunur, ancak çağdaş araştırmalarda en erken tarihli kullanım muhtemelen ünlü Sicilya tarihçisi Michele Amari'ye (öl. 1889) ait olandır. ${ }^{28}$

Netice olarak hem nisbenin okunuşuyla ilgili en erken tarihli izahın sahibi olan Sem‘ânî’yi dikkate almak, hem de onu takip eden çağdaş literatürle sürekliliği sağlayabilmek için bu nisbenin "es-Sakalî" şeklinde okunuşunun tercihe şâyân olduğu, bununla birlikte "es-Sakallî" ve "es-Sıkıllî" şeklinde okunuşunun da mümkün olabileceği tespit edilmiştir. Ülkemizde yapılan bazı çalışmalarda Ebü'l-Kāsım Abdurrahman'ın nisbesinin “es-Sicillî” olarak okunduğu görülür. Ancak hangi gerekçeyle bu şekilde bir okuma yapıldığı belirtilmemiştir. ${ }^{29}$

\section{Sakalî̀ye Yer Veren ya da Ona Değinen Kaynakların Değerlendirilmesi}

el-Envār ya da ed-Delāle 'alellāh eserlerinde yaşamına ilişkin hiçbir bilgi bulunmadığından Ebü'l-Kāsım Abdurrahman es-Sakalî'nin biyografisiyle ilgili bilgiler, büyük ölçüde, Riyâzzü’n-nüfûs'da yer alan rivayet ağlarına, Debbâğ'ın Me'âlimü'l-îmân'ındaki anlatısına ve Sehl b. Abdillah etTüsterîye atfedilen bazı yazmalardaki rivayet zincirlerine dayanmaktadır. Bunlardan öncelikle Sehl'e nispet edilen eserler, ardından tabakāt literatürü bağlamında Sakalînnin biyografisine dair bilgileri ele alıp tahlil edeceğiz.

\subsection{Sehl b. Abdillah et-Tüsterîye Atfedilen Eserlerde Sakalî ve İlim Çevresi}

Sakalînnin ismine, erken dönem tasavvufunun önemli simalarından Sehl b. Abdillah etTüsterîye nispet edilen eserlerin yer aldığı Köprülü Kütüphanesi 727 numarada kayıtlı Resâilü’tTüsterî başlıklı bir mecmuada rastlanmaktadır. Fuat Sezgin'in verdiği bilgiye göre hicrî yedinci

\footnotetext{
${ }^{26}$ Fuat Sezgin, GAS, 1/647, 666; a.mlf., Arap-İslâm Bilimleri Tarihi (İstanbul: Prof. Dr. Fuat Sezgin İslam Bilim Tarihi Araştırmaları Vakfı, 2015), 1/744, 766; a. mlf., Târîhu't-türâsi'l-Arabî, çev. Mahmûd Fevzî Hicâzî (Riyad: Câmiatü'lİmâm Muhammed b. Suud el-İslâmiyye, 1403/1983), 1/167. (Burada “es-Sakallî” şeklinde harekelendiği görülmektedir.)

${ }^{27}$ Benedikt Reinert, Die Lehre vom Tawakkul in der Klassischen Sufik (Berlin: De Gruyter, 1968), 293. Buradaki biyografik bilgiler, Brockelmann'ın verdiklerinin tekrarıdır.

${ }^{28}$ Michele Amari, Storia dei Musulmani di Sicilia (Firenze: Felice Le Monnier, 1854-1868), 2/495, 560. Amari'nin adı geçen eserinde söz ettiği “Abdurrahman es-Sıkıllî”, hicrî yedinci asırda yaşayan biri olup bu çalışmada ele aldığımız kişi değildir. Bununla birlikte bahsi geçen bölümde Sicilyalı sûfîlerle ilgili pasajlar bulunur (s. 490-495). Aynı şekilde "Ebû Bekir es-Sıkıllî" diye söz ettiği kişi (s. 480, dip. 5) burada ele aldığımız es-Sakalî değil, Ebû Bekir el-Mısrî'dir (öl. 345/956). Amari, Abdurrahman Câmî̀ye dayanarak ona neden "el-Mısrî" denildiğini soruşturur ve muhtemelen Sicilya'dan ayrıldıktan sonra bir müddet Mısır'da kalmış olabileceğini ifade eder. Ancak Câmî, Ebû Bekir elMısr̂̀'nin Sicilya kökeniyle ilgili herhangi bir bilgi vermez. Krş. Abdurrahman Câmî, Evliyâ Menkıbeleri: Nefahâtü'lÜns, çev. Lâmiî Çelebi, nşr. Süleyman Uludağ - Mustafa Kara (İstanbul: Pinhan Yayıncılık, 2011), 322.

${ }^{29}$ Fikret Karapınar, Muhaddis Sufilerin Hadis Usulü ve Hadisi Anlama Yöntemleri (H. IV-V./M. X-XI. Asır) (Konya: Selçuk Üniversitesi, Sosyal Bilimler Enstitüsü, Doktora Tezi, 2006), 4; Fatma Gedik, Sehl b. Abdullah et-Tüsterî ve Tasavvufi Görüşleri (Ankara: Ankara Üniversitesi, Sosyal Bilimler Enstitüsü, Doktora Tezi, 2019), 101. Araştırmamız sırasında nisbenin bu şekilde okunduğu başka hiçbir örneğe rastlayamadık.
} 
asırda istinsah edilen bu mecmua sırasiyla Kelâmu Sehl b. Abdillah (727/1, vr. 1a-153b), Kitâbu'ş-Şerh ve'l-beyân li mâ eşkele min kelâmî Sehl (727/2, vr. 154a-206a) ve Kitâbu'l-Mu'âraża ve'r-red 'alâ ehli'l-firak. ve ehli'd-da'âvâ fi'l-ahvâl (727/3, vr. 206a-243b) başlıklı birbirinden bağımsız üç risaleyi içerir. Bunlardan Kitâbu'ş-şerh ve'l-beyân'in müstakil bir başka nüshası, müstensih Ebû Bekir tarafından hicrî on ikinci yüzyılda istinsah edilen Esad Efendi 1623 (vr. 1a-42a) numarada yer alır, ancak iki nüsha arasında hiçbir ihtilaf tespit edilmemiştir. Hem Köprülü 727/2'nin hem de Esad Efendi 1623'ün başında müellifin ismi açık bir şekilde "Ebü'l-Kāsım Abdurrahman b. Muhammed es-Sakalî”" şeklinde geçmektedir. Kitâbu'ş-Şerh ve'l-beyân boyunca Sehl'in bazı sözleri nakledilmekte ve hemen ardından "Abdurrahman der ki...” şeklinde şerh kısımları gelmektedir. Köprülü 727/3'de de çok az bir kısmı hariç Sehl'in bütün sözlerinin ardından Sakalî’nin açıklamaları yer almaktadır. Bu durum söz konusu eserlerin hangi anlamda Sehl'e atfedilebileceği sorununu gündeme getirmiştir. Bu sorun hem Sehl hakkındaki doktora çalışmasında Gerhard Böwering, hem de her iki yazmayı da yayına hazırlayan Muhammed Kemal Ca'fer tarafından soruşturulduğu için, ${ }^{30}$ ayrıntısına girmeden onların tespitlerinden hareket edeceğiz. Onlara göre Kitâbu'ş-Şerh ve'l-beyân'in yapisal özellikleri, bu eserin bizzat Sakalî tarafından veya onun gözetiminde derlendiğini göstermektedir. Dolayısıyla en azından bu iki eserden Kitâbu'ş-Şerh ve'l-beyân'ı kesinlikle Sakalî̀ye ait bir eser olarak görmek ve Sakalî̀yi elMu'âraża ve'r-redd'in son derleyicisi ve râvisi olarak kabul etmek mümkündür. Bu bakımdan çalışmamız açısından önem arz eden husus, bu iki eserdeki rivayet zincirlerinin tespit edilerek Sakalî’nin ilim çevresi hakkındaki belirsizlikleri açıklı̆̆a kavuşturmaktır.

Sakalî el-Envār ve ed-Delāle 'alellāh eserlerinde hiçbir sûfînin ismini zikretmez, fakat Köprülü 727'ye kayıtlı mecmuada hem onun ilim çevresine hem de seyahatlerine ilişkin fikir veren rivayet zincirleri görülür. ${ }^{31}$ Buradaki bilgilerde, Sakalî’nin Sehl'in düşünceleriyle tanışması, Sehl'in

\footnotetext{
${ }^{30}$ Böwering, The Mystical Vision, 11-18; Ca'fer, "Temhîd ve Dirâse”, 50-64. Ca'fer, yukarıda söz konusu ettiğimiz Kitâbu'ş-Şerh ve'l-beyân'ı da Mine't-Türâsi's-Sûfil li Sehl b. Abdillah et-Tüsterî: ed-Dirâse ve't-tahkîk (Kahire: Dâru'l-Ma ârif, 1974) başlığıyla neşretmiştir, ancak bu çalışmayı edinme imkânı bulamadık. Bununla birlikte el-Mu'âraża ve'rredd'in baskısındaki hatalar ve eksiklikler göz önüne alındığında bizatihi yazma nüshalardan çalışmanın daha güvenilir sonuçlar vereceğini düşünüyoruz.

${ }^{31}$ Kitâbu'ş-Şerh ve'l-beyân'da: [1] Sakalî > Ebû Nasr el-Beledî (Mekke'de Mescid-i Harâm'da) > Ebû Ya'kûb en-Nehrecûrî > Sehl (Köprülü, 727/2, vr. 189a; Esad Efendi, 1623, vr. 29a). el-Mu'âraża ve'r-red'de: [2] Sakalî (Kayrevân'da) > Muhammed b. Abdillah en-Nihâvendî > Ebü'l-Hasen Ahmed b. Muhammed b. Sâlim (Basra'da) > Sehl (Köprülü, 727/3, vr. 206a). [3] Sakalî > Muhammed b. Ali eş-Şîrâzî (Medine'de Mescid-i Nebevî'de) > Muhammed b. Hafîf > Sehl (Köprülü, 727/3, vr. 206b). [4] Sakalî > Ebû Bekir Muhammed b. Ahmed et-Tarsûsî > İbrâhîm b. Şeybân el-Horasânî > Sehl (Köprülü, 727/3, vr. 206b). [5] Sakalî > Ebû Muhammed b. Abdillah en-Nifferî > Ali b. Mûsâ el-Basrî̀ Ömer b. Vâsıl > Hasan b. Sâlih el-Abâdânî > Sehl (Köprülü, 727/3, vr. 207a). [6] Sakalî̀ > Ebü’t-Tayyib el-Abbâs b. Ahmed elHâşimî > Ömer b. 'Avrî > Sehl (Köprülü, 727/3, vr. 207b). [7] Sakalî > Ebü’t-Tayyib el-Abbâs b. Ahmed el-Hâşimî > Ebû Bekir b. ez-Zekkâk > Sehl (Köprülü, 727/3, vr. 207b). [8] Sakalî > Ebû Bekir b. Ali el-Mevâzinî (Mısır'da) > Ahmed b. Sâlim > Sehl (Köprülü, 727/3, vr. 207b-208a). [9] Sakalî > Abdullah b. Hüseyin Ebû Muhammed el-Mutarriz > Ahmed b. Hasan el-Abbâs el-Mümetti' el-İstahrî > Sehl (Köprülü, 727/3, vr. 208a). [10] Sakalî > Ebû Bekir el-Horasânî > Ca'fer el-Huldî > Sehl (Köprülü, 727/3, vr. 208a).
} 
ardından talebeleri Ebû Abdillah İbn Sâlim (öl. 297/909) ile oğlu Ebü'l-Hasen Ahmed İbn Sâlim (öl. 356/967) tarafından kurulan Sâlimiyye ekolü ile ilişkisi ve nihayet sûfî çevrelerle olan irtibatı belirginleşir. Bilindiği gibi Sâlimiyye, bazı kelâmî duyarlılıklara sahip olmakla birlikte, daha çok tasavvufî bir okul olarak temâyüz etmiş, bilhassa Ebû Tâlib el-Mekkî (öl. 386/996) ve Ebû Hâmid elGazzâlî (öl. 505/1111) gibi müellifleri etkilemiştir. Bir değerlendirmeye göre bu okulun firak literatüründe ya da Hanbelî âlimlerin eleştirilerinde teşbih ve tecsim gibi birtakım suçlamalara konu olma nedeni, Sehl ya da İbn Sâlim'in değil; bu ekole hicrî beşinci asırda giren Hasan b. Ali elAhvâzînnin (öl. 446/1055) görüşleridir. ${ }^{32}$ Dolayısıyla Sakalî’nin bu ekolle irtibatını soruştururken, eleştirilere hedef olan "kelâm ekolü" anlamında Sâlimiyye'yi değil, tasavvufî bir ekol olarak Sâlimiyye'yi dikkate almak daha doğru olabilir. Bu çerçevede söz konusu rivayet zincirlerinde öne çıkan ve haklarında bilgi bulunan isimlerle Sakalî̀nin ilişkisini aşağıdaki şekilde irdeleyebiliriz.

Sakalînnin, el-Mu'âraża ve'r-redd'deki rivayet zincirinde Sâlimiyye'nin ikinci önemli ismi Ebü'l-Hasen Ahmed b. Sâlim ile -ki Sehl'e yetişmiş bir sûfîydi- doğrudan bir irtibatı olduğu tespit edilememektedir. İkisi arasındaki en önemli halkanın Muhammed b. Abdillah en-Nihâvendî (öl. [?]) olduğu anlaşılmaktadır, ancak bu kişi hakkında kaynaklarda hiçbir bilgi bulunmaz. Bununla birlikte el-Mu'âraża ve'r-redd'deki ifadelerden Ebü'l-Hasen Ahmed b. Sâlim'in çok yakın bir öğrencisi olduğu tespit edilebilir. Öte taraftan eserin en başındaki ifadelerden Sakalî̀nin el-Mu'âraża ve'r-redd'i Kayrevân'da talebelerine tahdis ettiği anlaşılmakta, bu da hem bu eseri hem de aynı biçimsel özelliklere sahip Kitâbu'ş-Şerh ve'l-beyân'ı aşağıda değineceğimiz üzere 350/961 yılındaki hac yolculuğu sırasında veya Kayrevân'a dönüşünde derlediğini göstermektedir.

Sakalî̀nin Mekke'de görüştüğü Ebû Nasr el-Beledî (öl. [?]), Nesef'de (bir başka adıyla Nahşeb) kadılık yapan bir muhaddis olarak bilinir. Kendisi Sehl et-Tüsterî̀nin meşhur Tefsî̀'inin râvîlerinden Ebû Bekir el-Beledî’nin dedesidir. Aslında Beledî ailesi, Sehl'in görüşlerinin yaygınlaşmasında üç nesil boyunca katkı sağlamış görünmektedir..$^{33}$ Ebû Nasr el-Beledî̀nin Sehl ile doğrudan görüşüp görüşmediği tam olarak bilinmemektedir. Bununla birlikte Ebû Nasr'ın, Sehl ile görüştüğü anlaşılan Ebû Ya'kûb en-Nehrecûrî (öl. 330/941) ile birlikteliğinden, Sehl'in görüşlerine aşina olduğu ve torunu Ebû Bekir Muhammed el-Beledî̀nin (öl. 504/1110) Sehl'in talebeleri ile ilişkisinin, bu irtibat

\footnotetext{
${ }^{32}$ Sâlimiyye ekolü hakkında doyurucu çalışma bulmak güçtür. En önemli sorun, Sehl, Ebû Abdillah İbn Sâlim ve Ebü’lHasen Ahmed b. Sâlim'in görüşleriyle sonraki dönemde eleştirilere konu olan yaklaşımların uyuşup uyuşmadığının tespit edilmesinde odaklanır. Sâlimiyye'yi daha çok bir "tasavvuf” okulu olarak betimleyen bir çalışma için bk. Cihat Tunç, Sahl b. 'Abdallāh at-Tustarī und die Sālimīya Übersetzung und Erläuterung des Kitāb al-mu'ārada (Bonn: Rheinische Friedrich-Wilhelms-Universität, Doktora Tezi, 1970); a.mlf., "Sâlimiyye”, Türkiye Diyanet Vakfi İslâm Ansiklopedisi (Ankara: TDV Yayınları, 2009), 36/50-51. Ebû Tâlib el-Mekkî’nin Sâlimiyye için önemi hakkında kayda değer bir çalışma için bk. Harith Bin Ramli, "The Sālimiyya and Abū Țālib al-Makkī: The Transmission of Theological Teachings in a Basran circle of mystics", Les maîtres soufis et leurs disciples des III'-V ${ }^{e}$ siècles de l'hégire (IX'$\left.X I^{e}\right)$ : Enseignement, formation et transmission, ed. Geneviève Gobillot \& Jean-Jacques Thibon (Damas-Beyrouth: Presses de l'Ifpo, 2012), 101-129.

${ }^{33}$ Böwering, The Mystical Vision, 107-109.
} 
vesilesiyle gerçekleştiği tahmin edilebilir. Başka bir deyişle Ebû Nasr el-Beledî’nin, Sakalî’nin Sehl et-Tüsterî’nin görüşleriyle tanışmasında önemli bir role sahip olduğu kanaatine varabiliriz.

Öte taraftan Nehrecûrînin Bağdat çevresindeki sûfîlerle ve özellikle Cüneyd ile ilişkisi dikkate alındığında, Sakalî’nin bu kanalla Cüneyd'in düşünceleriyle de tanışmış olabileceğini varsayabiliriz. Bu varsayımı destekleyen bir diğer rivayet ağı, Ebû Bekir el-Horasânî vasıtasıyla Cüneyd'in en yakın talebelerinden Ca‘fer el-Huldî̀ye (öl. 348/959) ${ }^{34}$ ulaşan silsiledir. Tüsterî̀nin vefatının ardından takipçilerinin önemli bir kısmının Basra'dan Bağdat'a, Cüneyd'in yanına gelmeleri dikkate alındığında, ${ }^{35}$ Sakalî’nin hem Sehl hem de Cüneyd'in görüşlerine yakinen vâkıf olabileceği düşünülebilir.

Söz konusu rivayet zincirlerinden anlaşıldığı kadarıyla Sakalî, tasavvuf tarihinde nevi şahsına münhasır bir sûfî olarak bilinen ve biyografisi hakkında çok kısıtlı bilgilere sahip olduğumuz Ebû Muhammed b. Abdillah en-Nifferî (öl. 354/965'ten sonra) ile doğrudan görüşmüştür. Nifferî elMevâkıf adlı eseriyle tasavvufî hâller ve makamlar konusunda vakfe görüşünü dile getirmiş önemli bir mutasavvıftır, ancak kimlerle irtibat halinde olduğu hâlâ meçhuldür. ${ }^{36} \mathrm{Bu}$ rivayet zinciri Nifferînnin muhtemelen Mısır'da Sakalî ile görüştüğünü, aynı zamanda muhtemelen Basra'daki Sâlimiyye ekolünden bir sûfî olan Ali b. Mûsâ el-Basrî ile de irtibat halinde olduğunu göstermektedir. Sakalî’nin Mısır'da Ahmed b. Sâlim ile irtibatlı olan Ebû Bekir b. Ali el-Mevâzinî’nin meclisinde bulunduğunu kendisi ifade ettiğine göre, Nifferî ile görüşmesi de ya hacca gidiş yolunda ya da dönüşünde gerçekleşmiş olmalıdır.

$\mathrm{Bu}$ rivayet ağında dikkati çeken bir diğer isim de İbn Hafîf eş-Şîrâzî'dir (öl. 371/982). Sakalî’nin Medine'de görüştüğü Muhammed b. Ali eş-Şîrâzî (öl. [?]), İbn Hafîf'in yakın talebelerinden biridir ve vefat ettiğinde onun yanına defnedilmiştir. ${ }^{37}$ İbn Hafîf in Sâlimiyye ekolü ile ilişkisi nispeten belirsizdir, çünkü hem üstatları Sehl'in müritleriydi, ${ }^{38}$ hem de İbn Sâlim'e bir reddiye yazmıştı. ${ }^{39}$ Sehl'in vefatından sonra talebelerinin bir kısmının Basra'da İbn Sâlim'in çevresinde kalmaları, bir kısmının ise Bağdat'ta Cüneyd'e intisap etmeleri göz önüne alındığında, İbn Hafîf'in

\footnotetext{
${ }^{34}$ Mustafa Kara, “Ca‘fer el-Huldî”, Türkiye Diyanet Vakfi İslâm Ansiklopedisi (Ankara: TDV Yayınları, 1992), 6/551.

${ }^{35}$ Gerhard Böwering, "Zulme Uğrayan ve İlhâdla Suçlanan İlk Sufîler”, çev. Abdurrezzak Tek, Uludağ Üniversitesi İlahiyat Fakültesi Dergisi 12/2 (2003), 378.

${ }^{36}$ Nifferî hakkında bk. Ekrem Demirli, "Nifferî”, Türkiye Diyanet Vakfi İslâm Ansiklopedisi (Ankara: TDV Yayınları, 2007), 33/81-82; M. Mustafa Çakmaklığlu, Hakikat Yolcusunun Son Durağı: Abdülcebbâr en-Nifferîye Göre Vakfe (İstanbul: Litera Yayıncılık, 2016). Nifferînnin el-Mevâkııf 1 dilimize tercüme edilmiştir. bk. Abdülcebbâr en-Nifferî, Mevâkıf, nşr. Nurullah Koltaş - Orkhan Musakhanov (İstanbul: Büyüyenay Yayınları, 2017).

${ }^{37}$ Sobieroj, Ibn-Hafíf aš-Šìrāzì, 215-216.

38 İbn Hafîf in Ebû Muhammed el-Cerîrî (öl. 321/933), Müzeyyin (öl. 328/939) ve Ahmed b. Yahyâ gibi bazı üstatları, Sehl'in de talebeleriydi. bk. Sobieroj, Ibn-Hafíf aš-Šîrāzī, 137-138. Ayrıca Sakalî̀nin rivayet zincirinde yer alan Ahmed b. Hasan el-Abbâs el-Mümetti' el-İstahrî hakkında bilgi için bk. a.mlf., Ibn-Hafî́ aš-šìrāzzì, 205.

${ }^{39}$ Böwering, "Zulme Uğrayan ve İlhâdla Suçlanan İlk Sufîler", 378-379.
} 
bağlantısının daha çok Bağdat üzerinden gerçekleşmiş olması daha olasıdır. Her hâlükârda Sakalî’nin Sehl'in düşünceleriyle ilgili kaynaklarından birinin de İbn Hafîf olduğu anlaşılmaktadır.

Öte yandan Sakalî ile Cüneyd arasındaki bağlantılardan birini de Ebü’t-Tayyib el-Abbâs b. Ahmed el-Hâşimî isimli sûfîyle görüşmesinden anlıyoruz. Ebü't-Tayyib'in kimliği şu an için belirsizdir, ancak görüşünü Sakalî̀ye aktardığı Ebû Bekir ez-Zekkâk, Cüneyd'e yakın olan isimlerden biriydi ve Mısır'da yaşıyordu. ${ }^{40}$ Dolayısıyla Ebü’t-Tayyib'in Zekkâk'ın talebesi olduğu düşünülürse, Sakalî’nin onunla Mısır'da görüşmüş olabileceği tahmin edilebilir.

Buraya kadar incelediğimiz isimler, Sakalînnin muhtemelen, 350/961 yllında hac vazifesini yerine getirmek için Kayrevân'dan çıktığı ve Mısır üzerinden Hicaz'a vardığı yolculuğu esnasında görüştügü sûfîleri ve bu yolculuk vesilesiyle Sehl'in ve çevresinin düşüncelerine vâkıf olduğunu, ama aynı zamanda Cüneyd önderliğindeki Bağdat tasavvuf anlayışı ile de tanıştığını ortaya koymaktadır. Sakalînnin Kayrevân'daki kimliğine ilişkin bilgileri ise ancak bu havzaya odaklanan tabakāt literatürü vasitasıyla vuzûha kavuşturmak mümkündür.

\subsection{Tabakāt Literatüründe Sakalî}

Sakalî’nin biyografisini belirginleștirmek için Mâlikî âlimlere hasredilen ya da onları içeren tabakāt literatürünün önemi yadsınamaz. Bununla birlikte söz konusu literatürün gelişim süreçleri ve yapısal özellikleri, Sakalî̀nin hâl tercümesine yer verme konusunda farklılaştıklarına işaret eder. Sakalî̀ye ilişkin en geniş biyografik değinilerin yer aldığı Me âlimü'l-îmân, müellif Abdurrahman b. Muhammed ed-Debbâğ'ın ardından İbn Nâcî et-Tenûhî’nin (öl. 839/1435) Ziyâdât'ı ile birlikte bugünkü formuna kavuşan kapsamlı bir eserdir. İbn Nâcînnin eklemelerinin genellikle Debbâğ’ın vefatından sonraki âlimleri kapsadığı bilinmektedir. Dolayısıyla Sakalî ile ilgili olan kısmın Debbâğ tarafından yazılmış olması kuvvetle muhtemeldir. Debbâğ, Sakalî’nin biyografisinde herhangi bir kaynağa atıf yapmaz. Ancak Me'âlimü'l-îmân'ı kaleme alırken yararlandığı eserler arasında bulunan ve Sakalî ile aynı ilim çevresine yetişmiş olan Mâlikî âlim Atîk b. Halef et-Tücîbînnin (öl. 422/1031) yazdığı -günümüze ulaşmayan-Tabakāt, Sakalî̀den bahsetmesi muhtemel bir kaynak gibi görünmektedir. Tücîbî’nin İbn Ebû Zeyd'in (öl. 386/996) öğrencisi olduğu ve İbn Ebû Zeyd ile Sakalî arasındaki görüş ayrılıkları hesaba katıldığında, Sakalî’den "eleștirel” bir üslupla bahsetmesi de muhtemeldir. ${ }^{41}$ Çünkü benzer bir tavır, Sakalî̀nin ismine sadece İbn Ebû Zeyd ile olan ihtilafı bağlaminda "Abdurrahman es-Sakalî” şeklinde yer veren Kādî İyâz’in (öl. 544/1149) Tertîbü’lmedârik'inde de görülür. ${ }^{42}$

\footnotetext{
${ }^{40}$ Ebû Abdirrahman es-Sülemî, Târîhu's-sûfiyye, thk. Muhammed Edîb el-Câdir (Dımaşk: Dâru Nînevâ, 2015), 74; Abdülkerîm el-Kuşeyrî, er-Risâletü'l-Kuşeyriyye, nşr. Abdülhalîm Mahmûd - Mahmûd b. Şerîf (Kahire: Metâbi'u Müessesetu'd-Dâru'ş-Şa‘b, 1989), 87; a.mlf., Tasavvuf İlmine Dair Kuşeyrî Risâlesi, çev. Süleyman Uludağ (İstanbul: Dergâh Yayınları, 2014), 22.

${ }^{41}$ Debbâğ - İbn Nâcî, Méâlimü'l-îmân, 3/158-159.

${ }^{42}$ Kādî İyâz, Tertîbül-medârik ve takrîbü'l-mesâlik li-ma'rifeti a lâmi mežhebi Mâlik, thk. Muhammed b. Tâvît et-Tancî v.dğr. (Rabat: Vizâretü'l-Evkâf ve'ş-Şuûni'l-İslâmiyye, 1981), 6/219.
} 
Öte taraftan Tertîbü'l-medârik, içerdiği isimlerin kimi zaman "dualarının müstecâb olması ve ferasetlerine" odaklanırken Me'âlimü'l-îmân, onların takva, vera' ve zühd gibi hasletlerinin yanında "kerâmetlerine" daha fazla yer veren bir üsluba sahip olmakla Tertîbü'l-medârik'ten ayrışır. Aslında hicrî dördüncü asırda bu bölgede yazıldı ̆̆ bilinen bazı eserler, âlimler ile zâhidlere farklı tabakāt eserlerinde yer verildiğini göstermektedir. Mesela tarihçi Ebü’l-Arab et-Temîmî’nin (öl. 333/945) Tabakātü 'ulemẩi Iffrîkıyye'den başka, bir de Kuzey Afrikalı zâhidlerden bahsettiği 'Ubbâdü Ifrîkıyye başlıklı bir eser kaleme aldığı bilinmektedir. ${ }^{43}$ Debbâğ'ın Me'âlimü'l-îmân'ı telif ederken bu eserden de istifade ettiği düşünülebilir. Başka bir anlatımla Debbâğ, tabakāt geleneğinde âlimler (fakihler, muhaddisler vb.) ile zâhidleri ve sûfîleri birbirinden ayıran bir yaklaşım yerine, iki üslubu da mezceden bir bakış açısının takipçisi olarak görünür ve bu yönüyle geleneksel Mâlikî tabakāt literatürünün dışına çıkar. Muhtemelen bu yaklaşımı miras aldığı kaynaklarından biri, Riyâzzü’nnüfûs'a sadece âlimleri değil zâhidleri de dâhil eden ve âlimlerin yaşadıkları dinî hayatın derûnî boyutlarıla ilgili çok sayıda rivayet nakleden Ebû Bekir el-Mâlikî'dir. ${ }^{44}$ Sûfîlerin ya da tasavvufî tavrın Mâlikî tabakāt literatüründe daha fazla yer bulduğu bu üslup değişimi, aşağıda ele alacağımız üzere velîlerin kerâmetleri bağlamında Sakalî ve İbn Ebû Zeyd arasında yaşanan tartışmanın, hicrî beşinci asır sonrasındaki Mâlikî fakihler ve sûfîler arasında en azından derinleşmediğini gösteren bir veri sayılabilir. Sakalî’den bahseden ya da ona değinen bu kaynaklardaki bilgiler kronolojik bir sırayla aşağıdaki şekilde incelenebilir.

\subsubsection{Ebû Bekir el-Mâlikînnin (öl. 494/1100 [?]) Riyâżü’n-nüfûs'unda Sakalî}

Ebû Bekir el-Mâlikînnin Riyâżü’n-nüfûs'unda Sakalî ilk bakışta sadece bir râvî olarak yer alır. Ebû Bekir el-Mâlikî onun Ebû Mâlik Sa'd b. Mâlik ed-Debbâğ (öl. 361/972), ${ }^{45}$ Ebü'l-Fazl el-Abbâs b. Muhammed es-Savvâf el-Ġadâmisî (öl. 349/961) ve Ebû İshâk İbrâhîm b. Ahmed es-Sebâî' (öl. 356/967) ${ }^{47}$ ile ilgili birer rivayetine yer verirken, Zehrûn b. Hasnûn el-Hammâl (öl. 339/951) ile ilgili bölümde de Sakalînnin İbn Ebû Zeyd'le olan tartışmasına değinir. ${ }^{48}$ Bu rivayetlerde "Abdurrahman b. Muhammed dedi ki..." şeklinde doğrudan Sakalı̂’den aktarım yaptı̆̆ı izlenimi verse de tarihsel

\footnotetext{
${ }^{43}$ Ali Öngül, “Ebü'l-Arab”, Türkiye Diyanet Vakfi İslâm Ansiklopedisi (Ankara: TDV Yayınları, 1994), 10/293.

${ }^{44} \mathrm{Bu}$ nedenle olsa gerek Riyâzü̈'n-nüfûs'u yayına hazırlayanlar eserin ismini Kitâbu riyâzzü'n-nüfûs fî tabakāti 'ulemâi'lKayrevân ve Ifrîklyye ve zühhâdihim ve nüssâkihim ve seyrin min ahbârihim ve fezâilihim ve evsâfihim şeklinde belirtmişlerdir.

45 “Abdurrahman b. Muhammed şöyle dedi: Ebû Mâlik Sa‘d b. Mâlik'in şöyle dediğini duydum: Allah kullarını belirli bir takdir üzere nimetlendirir, onlardan da güçleri ölçüsünce şükür talep eder." bk. Ebû Bekir el-Mâlikî, Riyâzzü’nnüfûs, 2/322. Ebû Mâlik ed-Debbâğ'ın vefat tarihi burada hicrî 334 olarak zikredilmiştir, ancak Me'âlimü'l-îmân' daki 361/972 tarihlendirmesi daha doğru görünmektedir. bk. Debbâğ - İbn Nâcî, Me‘âlimü'l-îmân, 3/79.

46 “Abdurrahman b. Muhammed şöyle dedi: Ebü'l-Fazl'ın şöyle dediğini duydum: Üç şey vardır ki, Fırat kıyısında ekinin bitmesi gibi kalpte nifak bitirir: Kötülük -bir başka nüshada "içki” olarak geçmektedir ki bu daha doğru görünmektedir-, sultanların kapısını aşındırmak ve şarkı dinlemek.” bk. Ebû Bekir el-Mâlikî, Riyâżü’n-nüfûs, 2/451.

47 “Abdurrahman b. Muhammed şöyle dedi: Ebû İshâk'ın şöyle söylediğini duydum: Bütün insanlar Allah'ı istiyorlar, fakat ben Allah'ın istediği kişiye bakıyorum.” bk. Ebû Bekir el-Mâlikî, Riyâżü’n-nüfûs, 2/503.

${ }^{48}$ Ebû Bekir el-Mâlikî, Riyâzü’n-nüfûs, 2/384. Zehrûn hakkındaki tek bilgi kaynağı Riyâzü̈n-nüfûs'tur (bk. 2/383-388).
} 
bakımdan -eğer Sakalî’nin sözlerini bir kitaptan nakletmiyorsa- Ebû Bekir el-Mâlikî ile Sakalî arasında en azından bir rivayet halkası daha bulunması olası görünmektedir. Ancak eserde bu kayıp halkaya yönelik fazla ipucu bulunmaz.

Ebû Bekir el-Mâlikî, Ebü'l-Fazl el-Ġadâmisî ile ilgili bölümde Fakih Ebû Bekir b. Abdirrahman'ın "Babam Abdurrahman bana Ebü'l-Fazl'ı ziyaret ettiğini aktarmıştır..." diye başlayan bir rivayetine yer verir. Buradaki Abdurrahman, "velî bir zât” olarak resmedilen Ebü'l-Fazl elĠadâmisî̀yi ilk kez ziyaret eden biri gibidir ve ondan kıtlık içerisinde olan Kayrevân için dua etmesini ister. ${ }^{49}$ Gadâmisî'nin 287/900'dan vefat ettiği 349/961 yılına kadar, kıyı kenti Münestîr'de yaşadığı kendi ifadesiyle sabit olduğuna göre, ${ }^{50}$ Sakalînnin Kayrevân'a oldukça yakın olan Münestîr'e böyle bir seyahati yapması mümkün görünmektedir. Ancak künyesi dışında Sakalînnin ailesi hakkında hiçbir bilgi bulunmadığı için buradaki râvînin onun oğlu olup olmadığı belirsizdir. ${ }^{51}$ Öte taraftan Ebü'l-Fazl el-Ġadâmisî ile ilgili başka bir rivayette birinin hacca gitmek üzere yola çıııp Ġadâmisîye uğradığı, ondan kendisine dua etmesini istediği, Ġadâmisînnin de bu kişiye oraya vardığında Hz. Peygamber'e selamını iletmesini istediği anlatılır. Rivayetin bu kısmı "Ebü'l-Kāsım şöyle dedi..." diyerek devam eder. Bu Ebü'l-Kāsım, hacca gittiğinde Ġadâmisînnin selamını iletmek üzere Mescid-i Nebevî̀ye vardığını ve salat ü selâmdan sonra "Ben Münestîr sakinlerinden falancayım..." diyerek Ġadâmisî’nin selamını ilettiğini, o esnada selamın kabul gördüŭğüne yönelik bir ses işittiğini ve bu sesin Hz. Ömer'e ait olduğundan emin olduğunu nakleder..$^{52}$ Ebû Bekir elMâlikî’nin kaynakları arasında iki “Ebü'l-Kāsım” bulunur: Ebü'l-Kāsım Abdurrahman b. Muhammed es-Sakalî (öl. 380/990 [?]) ve Ebü'l-Kāsım Abdurrahman b. Muhammed el-Lebîdî (öl. 441/1049). Lebîdînnin bu rivayette haccı yapan kişi olması tarihsel olarak pek olası görünmediğinden bu kişinin Sakalî olabileceği, dolayısıyla Sakalî'nin bir müddet Münestîr'de de ikamet etmiş olabileceği düşünülebilir. Dolayısıyla bu ihtimal, Sakalînnin sadece bir "râvî" kimliği ile değil, Ebü’l-Fazl elGadâmisî ile daha yakın bir ilişki içinde olduğunu akla getirir ki çağdaş araştırmalarda bu isme hiç dikkat çekilmemiştir.

"Kendisinden kerâmetler zuhur eden Kayrevânlı bir müteabbid, nâsik ve müçtehit" olan Zehrûn ile ilgili bölümde ise Ebû Bekir el-Mâlikî, bu kişi hakkındaki rivayetlere geçmeden önce iki şahıs arasındaki bir konuşmayı nakleder. Bu iki şahıstan ilki râvî Ebû Abdillah Muhammed b. Heybûn, diğeri ise ünlü Mâlikî âlimi Ebû İshâk b. Şa'bân'ın (öl. 355/966) talebelerinden biri olarak tanıtılan Ebû Abdillah Muhammed b. Yahyâ el-Ecdâbî'dir. İbn Heybûn hacca gitmek üzere yola çıktığında Ecdâbiyye'ye gelerek Ebû Abdillah el-Ecdâbî̀ye uğradığını, buluşmalarının 382/993'te "Abdurrahman İbn Sakalî" ile -buradaki İbn kelimesi açıkça hatalıdır- İbn Ebû Zeyd arasındaki

\footnotetext{
${ }^{49}$ Ebû Bekir el-Mâlikî, Riyâżü'n-nüfûs, 2/444-445.

${ }^{50}$ Ebû Bekir el-Mâlikî, Riyâżü'n-nüfûs, 2/440.

${ }^{51}$ Bir de İbn Ebû Zeyd'in öğrencileri arasında gösterilen Ebû Bekir b. Abdirrahman bulunur. bk. Kādî İyâz, Tertîbü'lmedârik, 6/217.

${ }^{52}$ Ebû Bekir el-Mâlikî, Riyâżü'n-nüfûs, 2/443-444.
} 
olayın ardından gerçekleştiğini ve insanların hâlâ İbn Ebû Zeyd'i kerâmeti inkâr ettiği gerekçesiyle kötülediklerini belirtir. Ebû Abdillah el-Ecdâbî, İbn Ebû Zeyd'in kerâmeti inkâr eden bir görüşünün kendilerine hiç ulaşmadığını ifade eder. İbn Heybûn da söz konusu olayı Ecdâbî̀ye olduğu gibi aktardığını belirterek İbn Ebû Zeyd'in böyle bir görüşünün olmadığını söyler. Bunun üzerine Ecdâbî sevinir ve hocası Ebû İshâk b. Şa'bân'ın kendilerine "sâlihlerin kerâmetlerinden pek çok şey" anlattığını ve hocasını onların yolunun bir "takipçisi" olarak gördüğünü belirtir. ${ }^{53}$

Sakalî ile İbn Ebû Zeyd arasındaki görüş ayrıllı̆ının yazılı bir kaynakta zikredildiği muhtemelen ilk yer burasıdır ve bu anlatı bize iki şeyi gösterir: Birincisi söz konusu tartışma 382/993'ten kısa bir süre önce gerçekleşmiştir. Bu durum Sakalî’nin 380/990 ilâ 382/993 arasındaki bir dönemde vefat etmiş olabileceğini gösterir. Çünkü Debbâğ'ın tarihlendirmesine göre Sakalî kesinlikle İbn Ebû Zeyd'den önce vefat etmiştir. İkincisi ise İbn Ebû Zeyd de dâhil olmak üzere Mâlikî âlimlerin genel olarak tasavvufa özelde ise kerâmetlere mutlak anlamda karşı olmadıkları düşüncesi dile getirilmektedir ki bu tutumu Kādî İyâz da yineleyecektir. Riyâżü’n-nüfûs'da Sakalî’nin rivayette bulunduğu yukarıdaki isimlerden Ebû Mâlik ve Ebû İshâk es-Sebâî̀ ise, aşağıda değineceğimiz üzere, Me'âlimü'l-îmân'da Sakalînnin ders aldığı üstatları arasında sayılmaktadır. Bu da Sakalînnin ilim çevresiyle ilgili Debbâğ'ın kaynaklarından birinin Ebû Bekir el-Mâlikî olabileceğini göstermektedir.

\subsubsection{Kādî İyâz'ın (öl. 544/1149) Tertî̉ül'-medârik'inde Sakalî}

Bu kapsamlı tabakāt eserinde Sakalî’nin ismi sadece velîlerin kerâmetleri konusunda İbn Ebû Zeyd ile olan ihtilafı bağlamında bir kez geçer ve kendisi için ayrıca bir biyografi tahsis edilmemiştir. Kādî İyâz'in İbn Ebû Zeyd'in biyografisi çerçevesinde verdiği bilgilere göre, İbn Ebû Zeyd Kitâbü'lİstizhâr fi'r-red 'ale'l-Fikriyye ve Kitâbu Keşfi't-telbîs eserlerini, kerâmetleri anlatan "Abdurrahman esSakalî’nin kitabına" reddiyeler olarak yazmış, bu nedenle sûfîler ve ehl-i hadisten pek çok âlim onu kötülemiştir. İbn Ebû Zeyd'in kerâmetleri tamamen inkâr ettiği - ki Kādî İyâz'a göre aslında bunu kastetmemişti- düşüncesi yayılınca da Endülüs ve Doğu bölgelerinden pek çok âlim tartışmaya dâhil olmuş, bu kapsamda Ebü'l-Hasen İbn Cehdâm el-Hemedânî (öl. 414/1023), Ebû Bekir el-Bâkıllânî (öl. 403/1013), Ebû Abdurrahman b. Şakkü’l-Leyl (öl. 455/1063) ve Ebû Ömer et-Talemenkî (öl. 429/1037) gibi âlimler, İbn Ebû Zeyd'e karşı kerâmetlerin cevâzına dair eserler yazmışlardır. Ardından Kādî İyâz, Ebû Bekir el-Bâkıllânînin İbn Ebû Zeyd'in kerâmetleri inkâr etmediğini düşündüğünü Bâkıllânî, İbn Ebû Zeyd'den fikıh tahsil etmişti-, Ebû Ömer et-Talemenkî̀nin ise İbn Ebû Zeyd'in kerâmetleri tamamen inkâr etmediğini ve nübüvveti korumayı amaçladığını, tam aksine bu hususta insanları istismar edenlere karşı çıktığını söylediğini aktarmıştır. Bu bağlamda Kādî İyâz onun Hızır'ın varlığını caiz gördüğünü anlatan bir rivayete de yer vermiştir..$^{54}$ Öte taraftan Kādî İyâz, İbn Ebû Zeyd'in talebelerinden Ebü'l-Hasen Ali b. Muhammed el-Kābisînnin (öl. 403/1012) eserleri arasında da er-Risâletü'n-nâșıriyye fi'r-red 'ale'l-Fikriyye başlıklı bir reddiyeyi zikretmiştir. ${ }^{55}$

\footnotetext{
${ }^{53}$ Ebû Bekir el-Mâlikî, Riyâżü'n-nüfûs, 2/383-384.

${ }^{54}$ Kādî İyâz, Tertîbü'l-medârik, 6/219-220.

${ }^{55}$ Kādî İyâz, Tertîbü’l-medârik, 7/96.
} 
Kādî İyâz'ın anlatımında öncelikle ilk kez Sakalîye "Fikriyye" diye bir firkanın nispet edildiğini görmekteyiz. Bu isimlendirme konusunda sonraki dönem Mâlikî tabakātında farklı tutumlar gözlenir. İbn Ferhûn'un (öl. 799/1397) ed-Dîbâcül-müzheb'inde İbn Ebû Zeyd'in eseri Kitâbü'l-istizhâr fi'r-red 'ale'l-Fikriyye olarak geçerken; ${ }^{56}$ Kābisî'nin eseri er-Risâletü'n-nâșıriyye fi'r-red 'ale'l-Bekriyye olarak geçer. ${ }^{57}$ Mahlûf un Şeceretü'n-nûr'unda ise İbn Ebû Zeyd'in bütün eserleri zikredilmiş, fakat Sakalî̀ye yazdığı reddiyeye yer verilmemiş, ${ }^{58}$ Kābisînnin eseri ise er-Risâletü’nnâsıriyye fi'r-red 'ale'l-Bekriyye olarak kaydedilmiștir. ${ }^{59}$ Son olarak Mahfûz ise İbn Ebû Zeyd'in biyografisinde bu firkayı "Bekriyye" olarak kaydederken, ${ }^{60}$ Kābisînnin biyografisinde bu firkanın "Fikriyye" değil, "Bekriyye" olduğunu ve bu isimlendirmenin "Sakalînnin takipçilerini” ifade ettiğini belirtmiştir. ${ }^{61}$ Başka bir anlatımla Fikriyye isminin hicrî dokuzuncu asırdan itibaren Bekriyye'ye dönüştüğü görülür, bu da "Bekriyye" isimlendirmesinin Sakalînnin takipçilerini ifade etmek üzere hicrî dördüncü asırda kullanıldığı tezini zayıflatmakta, bunun daha çok "el-Bekrî" nisbesinden hareketle Sakalî̀ye atıf yapan bir isimlendirme olabileceğini akla getirmektedir. ${ }^{62}$ Bununla birlikte hem Sehl'e nispet edilen eserlerdeki rivayet ağları ve eserlerin nakledilme biçiminden hem de Debbâğ’n Sakalî̀yi bir “tarikat şeyhi” olarak niteleyen övgü ifadelerinden, Sakalî’nin müritlerinin ve takipçilerinin olabileceği göz ardı edilemez.

Bu belirsizliklere rağmen Kādî İyâz'ın verdiği bilgilerden çıkan kesin bir sonuç bulunur: Hicrî dördüncü yüzyılda Kayrevân'da yaşanan bu ihtilaf Kuzey Afrika sınırlarını aşarak Bağdat, Mekke ve Endülüs gibi İslâm dünyasının farklı muhitlerine yayılmıştır. Bu tartışmaya dâhil olduklarında İbn Cehdâm Mekke'de, Bâkıllânî muhtemelen Bağdat'ta, İbn Şakkü'l-Leyl ve Talemenkî ise Endülüs'te bulunuyorlardı. Dahası bu ihtilafın özellikle Endülüs bölgesinde bir tür tasavvuf karşıtlı̆̆ı hareketini

\footnotetext{
${ }^{56}$ Burhâneddin İbn Ferhûn, ed-Dîbâcü'l-müzheb fî ma'rifeti a'yâni 'ulemâ'i’l-mežheb, thk. Muhammed el-Ahmedî Ebü’nNûr (Kahire: Dâru't-Türâs, 1972), 1/430.

${ }^{57}$ İbn Ferhûn, ed-Dîbâcü'l-müzheb, 2/102.

${ }^{58}$ Mahlûf, Şeceretün-nûr, 1/143-144.

${ }^{59}$ Mahlûf, Şeceretü'n-nûr, 1/145.

${ }^{60}$ Muhammed Mahfûz, Terâcimü’l-müellifine't-Tûnisiyyîn (Beyrut: Dâru'l-Garbi'l-İslâmî, 1402-1406/1982-1986), 2/444445.

${ }^{61}$ Mahfûz, Terâcimü'l-müellifin, 4/48-49.

${ }^{62}$ Kelâm tarihi bağlamında Bekriyye, Bekr b. Uhtü Abdülvâhid b. Zeyd'e (öl. hicrî üçüncü asır [?]) nispet edilen ve mürtekib-i kebire ya da istitāat gibi hususlarda kimi yönlerden Mu'tezile'ye yaklaşan bir firka olarak nitelendirilir. Bu bağlamda Josef van Ess, İbn Ebû Zeyd ve ondan önce yaşayan Mâlikî âlim İbn Sahnûn'un (öl. 256/870) Kitâbü’rred 'ale'l-Bekriyye isimli eserlerini buradaki Bekr b. Uhtü Abdülvâhid b. Zeyd'e nispet edilen Bekriyye firkasıyla ilişkilendirir. Bununla birlikte İbn Ebû Zeyd'in eserindeki Bekriyye'nin kimleri ifade ettiğinin belirsiz olduğunu dile getirir. bk. Josef van Ess, Theology and Society in the Second and Third Century of the Hijra, çev. John O'Kane - Gwendolin Goldbloom (Leiden: Brill, 2017-2019), 2/127, 136. Başka bir anlatımla Mâlikî âlimlerin Bekr b. Uhtü Abdülvâhid b. Zeyd'e nispet edilen Bekriyye fırkasına yönelik reddiyeler yazdıkları kesindir, ancak konumuz bağlamında İbn Ebû Zeyd'in reddiyesinin Sakalîye karşı yazmış olduğu da aynı oranda açıktır.
} 
beslediği ya da oradaki tartışmaları etkilediği görülmektedir. ${ }^{63}$ Aslında İbn Ebû Zeyd ve Kābisînnin eserlerindeki "Fikriyye" ifadesi, Kādî İyâz’ın verdiği bağlam olmasa, bu eserlerin ilk bakışta "tefekkür" kavramına özel bir önem atfeden Endülüslü sûfî-filozof İbn Meserre’ye (öl. 319/931) karş1 bir reddiye olduğu izlenimini vermektedir. Her hâlükârda bu tartışma, Kayrevân'daki tasavvuf savunusunun, tasavvufun dinî ilimlerle bir tür "uzlaşı" sağlayarak "dinî ilim” karakterine büründüğü hicrî dördüncü yüzyıl Bağdat'ındaki şeriat-hakikat tartışmalarına eklemlenebileceğini, ${ }^{64}$ yani benzer bir sürecin Kuzey Afrika'da da yaşandığını açıcça göstermektedir.

Öte yandan Venşerîsînnin (öl. 914/1508) Mâlikî fetvalarını derlediği ansiklopedik eseri elMi'yârrü'l-mu'rib'inde ayrıntılı bir şekilde yer bulmasından, bu tartışmanın Mâlikî fıkıh-kelâm düşüncesi için de önem arz ettiği değerlendirilebilir. Venşerîsînnin bu tartışmaların başlangıcıyla ilgili anlatısı başka kaynaklarda bulunmaz. Onun aktardıklarına göre bir adam İbn Ebû Zeyd'e gelip rüyasında "harikulâde" şeyler gördüğünden bahsetmiş; İbn Ebû Zeyd bunun mümkün olabileceğini belirtmiş, ancak aynı adam bu kez Allah'ı “yakaza” halindeyken gördüğünü söyleyince İbn Ebû Zeyd karşı çıkarak meşhur reddiyeyi kaleme almıştır. ${ }^{65}$ Burada "adamın" ismi zikredilmez, bu da söz konusu kişinin Sakalî değil, fakat onun müritlerinden veya takipçilerinden biri olabileceğini düşündürür.

\subsubsection{Debbâğ'ın (öl. 699/1300) Me âlimül'-îmân'inda Sakalî}

Debbâğ, Sakalî’nin biyografisine müstakil olarak yer veren ve ele aldığı diğer bütün isimlerden farklı olarak onu şeyh, ârif, muhakkik, hakikat imâmı ve tarikat ehlinin şeyhi şeklinde niteleyen ilk yazardır. Onun anlatısını yukarıdaki örneklerinden ayıran temel hususlar, Sakalînnin hocaları, seyahatleri, irtibatlı olduğu âlimler, temel görüşleri ve eserleri hakkında bilgi vermesi ve günümüze ulaşmayan bir eserinden pasajlar aktarmasıdır. İbn Ebû Zeyd ile olan ihtilafı burada da söz konusu edilir, fakat hem Sakalîyi hem de İbn Ebû Zeyd'i kişilikleri bakımından uzlaştıran orta yolcu bir yaklaşım dışında diğer anlatılardan farklılaşmaz.

Debbâğ'ın verdiği bilgilere göre Sakalî, Kayrevân'da Ebü'l-Hasen Ali b. Muhammed b. Mesrûr ed-Debbâğ, Habîb b. Nasr el-Cezerî, Ebü'l-Arab Muhammed b. Ahmed b. Temîm, Ziyâd b. Yûnus el-

\footnotetext{
${ }^{63}$ Endülüs'teki tasavvuf karşıtlı̆̆ı ve evliya kerâmetleri hakkındaki tartışmaları ayrıntılı bir şekilde alan ve Kayrevân'daki ihtilafla ilişkilendiren çalışmalar için bk. Maribel Fierro, "The Polemic about the 'karāmāt al-awliyā", and the Development of Șūfism in al-Andalus (Fourth/Tenth-Fifth/Eleventh Centuries)", Bulletin of the School of Oriental and African Studies 55/2 (1992), 236-249; a.mlf., "Endülüs'te Tasavvufa Muhâlefet = Opposition to Sufism in al-Andalus”, çev. Semih Ceyhan, Uludağ Üniversitesi İlahiyat Fakültesi Dergisi 18/2 (2009), 327-359. İbn Meserre ve hakkındaki ihtilaflar için bk. Ercan Alkan, Şerhu Hal'i'n-Na'leyn: Hal'u'n-Na'leyn Şerhi (İstanbul: Türkiye Yazma Eserler Kurumu Başkanlığı Yayınları, 2017), 35-69.

${ }^{64} \mathrm{Bu}$ konuya odaklanan çalışmalar için bk. Abdullah Kartal, Tasavvufun Oluşumu: Şeriat-Hakikat İlişkisi (Bursa: Emin Yayınları, 2015); Hacı Bayram Başer, Şeriat ve Hakikat: Tasavvufun Teşekkül Süreci (İstanbul: Klasik Yayınları, 2017).

${ }^{65}$ Venşerîsî, el-Mi'yârü'l-mu'rib ve'l-câmi'u'l-muġrib 'an fetâvâ 'ulemẩi Iffrîkıyye ve'l-Endelüs ve'l-Mag̉rib, nşr. Muhammed Hacî (Rabat: Vizâretü'l-Evkâf - Beyrut: Dâru'l-Garbi'l-İslâmî, 1401/1981), 2/442-443. Aynı eserde Bâkıllânî ve diğer Mâlikî âlimlerin kerâmet konusundaki görüşleri için bk., 2/387-393, 11/248-252.
} 
Yahsubî, Ebû İshâk b. İbrâhîm b. Ahmed es-Sebâî', Sa'd b. Mâlik b. 'Ubbâde ve Ebû cíkâl'in talebesi Ebû Bekir b. Sa'dûn'dan ilim tahsil etmiştir. Ardından Doğu'ya seyahat etmiş, Ebû Abdillah Muhammed b. Ahmed b. İbrâhîm el-Belhî, Ebü'l-Hasen Ali b. Ahmed b. Zekeriyyâ el-Hâşimî, Ali b. Hüseyin b. Findâr el-Kâdî ve Ebû Bekir b. Atîk b. Mûsâ b. Hârûn el-Hâtemî ile görüşmüş, 350/961 yılında Mekke'de Ebû Bekir Muhammed b. Hüseyin el-Âcurrî'den ders almıştır. Hadis, fikıh, usûl-i fıkıh ve tasavvuf konularında uzmanlaşan Sakalî, pek çok eser de telif etmiştir. Debbâğ bunlardan el-Envāru's-Sakalî diye isimlendirilen eseri, "daha önce kimsenin bahsetmediği türden tasavvufî sırları ve marifet türlerini içeren, tasavvufun kaidelerini Kur'ân, sünnet ve ilk selef nesline göre inşa ederek rey ile istihsânın terkini öneren" bir kitap olarak tanımlar. Ayrıca Sakalînnin Șıfaü̈l-evliyā’ ve merātibu aḥvāli'l-asfiyā', Kerāmātü'l-evliyā' ve'l-muțiine mine's-sahābe ve't-tābi'ine ve men tebi'ahum bi ihsān isimli eserleri olduğunu söyler ${ }^{66}$ ve sonuncusundan kısa bir bölüm aktarır. ${ }^{67}$ Bu pasajdan sonra Debbâğ, Sakalî ile İbn Ebû Zeyd arasındaki ihtilafa değinir. Debbâğ, Sakalî̀nin kalp gözüyle görme anlamında velîlerin kerâmetleri hususunda aktardığı pek çok şeyi İbn Ebû Zeyd'in inkâr ettiğini, bunun ise Allah'ın velîlerine bahşettiği kerâmetleri ve kalplerine feyz olunan nur ve bereketleri anlamamasından kaynaklandığını belirtir. Debbâğ, Sakalî’nin, Allah'ın velîlerine bu türden ihsanları bahşedecek kudretini inkâr eden fakihlerin hatalarına kitabında işaret etmesinin sebebini bununla açıklar. Ancak Debbâğ bir yönüyle İbn Ebû Zeyd'i de haklı görerek, o dönemde Allah'ı uyanık (yakaza) haldeyken gözle gördüklerini iddia eden çok sayıda mürit bulunmasının İbn Ebû Zeyd'in itirazının esas nedeni olduğunu dile getirir. Kādî İyâz’ın başka âlimlerin de bu tartışmaya katılmasıyla ilgili anlatısını Debbâğ, çağdaşı Mâlikî âlim İbn Bezîze'nin (öl. 673/1274) anlatımıyla aktarır ve burada da Bâkıllânînin İbn Ebû Zeyd hakkındaki övgü dolu ifadelerine yer verir. Debbâğ son olarak Sakalînnin

\footnotetext{
${ }^{66}$ Debbâğ - İbn Nâcî, Méâlimü'l-îmân, 3/144-145.

${ }^{67} \mathrm{Bu}$ pasajı önemine binaen buraya aktarmakta yarar görüyoruz. Çünkü bu eser günümüze ulaşmadığı gibi, İbn Ebû Zeyd'in itirazlarına kaynaklık teşkil edecek türde kerâmet olaylarını da içermektedir. Köşeli parantezler tarafımızdan eklenmiştir: “eş-Şeyh Ebü'l-Kāsım Abdurrahman -ki Allah ondan razı olsun- şöyle demiştir: Bana Şeyh İmâm Ebû Bekir b. Sa'dûn et-Temîmî şöyle haber vermiştir: Bana biri misafir olmuştu ve evde ikram edecek hiçbir şeyim yoktu. Etrafa bakındım ve bir parça tatlı buldum. Bunu ikram etmenin iyi olacağını düşündüm. [ïbn Sa'dûn devamında] şöyle dedi: Tatlıyı misafire ikram edince şunu anlattı: Mekke'den ayrılacağım gündü ve hiç param yoktu. Ebû 'íkâl bana şöyle dedi: 'Seni kendisinden ümit kesilmeyen ve duacısını eli boş bırakmayana ısmarlıyorum!' [Adam şöyle devam etti] Vallahi Mekke'nin sokaklarından öylece çıııp gittim, yanımda yükümden başka hiçbir şey yoktu ve Kayrevân'a varıncaya kadar da bu şekilde geldim. Ebü’l-Kāsım [es-Sakalî] şöyle dedi: Abdullah b. Sa îd b. Haddâd bana Ebû Muazzel'in şöyle dediğini bildirdi: el-Lahmînnin yanına vardığımda diyordu ki: 'Altı aydır su içmeden duruyorum.' 'Neden' diye sorunca 'Nefsimden bir an için razı oldum ve bu beni mutlu etti, o yüzden!' dedi. Ebü'l-Kāsım [es-Sakalî] şöyle dedi: Ebû Mâlik, Tâhertî’nin şunu söylediğini dediğini aktardı: Muhammed b. Ebî Hamîd'i -ki gençken vefat etmişti- görmüştüm. Yanında ölümden bahsedilince şöyle dedi: 'Ölüm de neymiş! Ey ölüm meleği! Gir içeri!' Baktılar ki oracıkta vefat etmiş. Allah rahmet eylesin!” bk. Debbâğ - İbn Nâcî, Me'âlimü'l-îmân, 3/145.
} 
vefat tarihini tespit edemediğini, ancak İbn Ebû Zeyd'den (öl. 386/996) önce vefat ettiği bilgisini verir. ${ }^{68}$ Burası Sakalî’nin vefat tarihine ilişkin şimdiye kadar zikredilen ilk bilgi olarak dikkati çeker.

Debbâğ'ın verdiği bilgiler, çalışmamızın başında incelediğimiz üzere Sehl'e nispet edilen eserlerdeki verilerle birleştirildiğinde, Sakalî’nin biyografisine ilişkin bütüncül bir anlatıma ulaşmamıza imkân verecek kapsamdadır. Bununla birlikte Âcurrî dışında, onun Doğu'ya gerçekleştirdiği seyahat esnasında görüştüğü kişilerle ilgili kaynaklarda herhangi bir bilgiye rastlanmaz. Sehl'e nispet edilen eserlerdeki bilgilerde kesin olan husus, Sakalînnin Mekke, Medine ve Mısır'da bulunmuş olmasıdır. Dolayısıyla İbrâhîm el-Belhî, Ebü'l-Hasen el-Hâşimî, Ali el-Kādî ve Ebû Bekir el-Hâtemî gibi isimlerle bu üç merkezde görüştüğü düşünülebilir.

Sakalî’nin Kayrevân'da dinî ilimleri kendilerinden tahsil ettiği kimseler ise Mâlikî geleneğin önde gelen âlimleridir. Bunlardan Ebû İshâk es-Sebâ̂’’ (öl. 356/967), başta İbn Ebû Zeyd, Ebü’l-Kāsım İbn Şeblûn ve Kābisî olmak üzere önde gelen Mâlikî âlimlerin hocalığını yapmış, takva, vera‘ ve ibadete düş̌ünlüğü ile temâyüz etmiş isimlerden biri olarak dikkati çeker. Kaynaklarda Sebâî’nin "kerâmetleri" bahsinde çok sayıda olayın nakledilmesi, Mâlikî gelenek içerisinde onun şerî̀ ve derûnî hayatı mezceden bir kişi olarak görüldügüne işaret eder. ${ }^{69}$ Öte taraftan Sakalî̀nin, velîlerin kerâmetleri bağlamında ihtilaf yaşadığı İbn Ebû Zeyd ile aynı hocaya talebelik yaptığı anlaşılmaktadır.

Ebü'l-Hasen ed-Debbâğ (öl. 359/970), Kayrevân ve Mısır'da pek çok âlimden tahsil görmüş, dönemin Mâlikî fakihlerinin muteber saydığı, zengin ve hayırsever bir kişi olarak tanınmaktadır. Dindarlığına düşkün biri olarak bilinen Debbâğ, bu özelliği ile Sebâ̂̂ ile karşılaştırılmış ve Mâlikî âlimler Debbâğ’ âbid, Sebâî̀yi ise âlim olarak nitelemişlerdir. Sakalî̀nin çağdaşı Ebü'l-Hasen elKābisînnin de aralarında bulunduğu pek çok âlimin hicrî 333-356 yıllarında arasında ondan ilim tahsil ettiği bilinmektedir. ${ }^{70}$ Dolayısıyla Sakalî’nin Mekke'ye yolculuğundan önce Debbâğ’a öğrencilik yapmış olması kuvvetle muhtemeldir.

Ebü'l-Kāsım Ziyâd b. Yûnus (öl. 361/972), Kayrevân ve Mısır'da tahsil görmüş ve çok sayıda âlim yetiştirmiş bir muhaddistir. İlimdeki yetkinliği sebebiyle Endülüs, Trablus ve Kuzey Afrika'nın farklı bölgelerinden insanların ondan ilim tahsil etmeye geldikleri bilinir. ${ }^{71} \mathrm{Bu}$ bakımdan Sakalînnin hadis tahsil ettiği âlimlerden biri de muhtemelen Ziyâd b. Yûnus'tur.

Debbâğ'ın Sakalî’nin hocaları arasında saydığı Sa'd b. Mâlik b. 'Ubbâde ya da tam ismiyle Ebû Mâlik Sa‘d b. Mâlik b. 'Ubbâde ed-Debbâğ (öl. 361/972) ise diğerlerinin aksine sûfi kimliği ile öne çıkan bir isimdir. Me'âlimü'l-îmân'daki bilgilere göre Ebû Mâlik, tasavvufta fenâ ve bekā konusunu ilk kez detaylıca ele alan ünlü mutasavvıf Ebû Sa îd el-Harrâz’ın (öl. 286/899) öğrencisiydi. Debbâğ, bu

\footnotetext{
${ }^{68}$ Debbâğ - İbn Nâcî, Méâlimü'l-îmân, 3/146.

${ }^{69}$ Ebû Bekir el-Mâlikî, Riyâzü̈n-nüfûs, 2/469-508; Kādî İyâz, Tertîbü’l-medârik, 6/54-76; Debbâğ - İbn Nâcî, Me'âlimü'lîmân, 3/63-74; İbn Ferhûn, ed-Dîbâcü'l-müzheb, 1/362-364.

${ }^{70}$ Kādî İyâz, Tertîbül-medârik, 6/258-262; Debbâğ - İbn Nâcî, Me âlimü'l-îmân, 3/75-78.

${ }^{71}$ Debbâğ - İbn Nâcî, Me âlimü'l-îmân, 3/79.
} 
bilgiyi Sülemî’nin Târîhu's-sûfiyye'sinden aktardığını nakleder. Ancak M. Edîb el-Câdir'in yayına hazırladığı versiyonda Ebû Mâlik'e ait bir bilgi bulunmaz. ${ }^{72}$ Bu durumda Ebû Mâlik, Târihu'ssûfiyye'nin günümüze ulaşmayan bir başka nüshasında Harrâz'ın talebesi olarak zikredilmiş olabilir. Sûfi kimliğinin yanı sıra Ebû Mâlik, "emanet, sıdk ve tevâzu gibi erdemlerle donanmış bir ârif, Kur'ân ehli ve hakikat ilmi konusunda üstat" olarak tanınmıştır. ${ }^{73}$ Her hâlükârda Ebû Mâlik'in mutasavvif kimliği belirgindir ve Sakalînnin tasavvuf düşüncesine etki etmiş olması kuvvetle muhtemeldir.

Bir fakih, muhaddis ve tarihçi olarak dikkati çeken Ebü’l-Arab et-Temîmî (öl. 333/945), hem dönemin birtakım siyasi olaylarındaki tutumuyla âlimlere önderlik etmiş hem de İbn Ebû Zeyd başta olmak üzere pek çok Mâlikî âlimin yetişmesine katkı sağlamış velûd bir âlimdir. ${ }^{74}$ Eğer vefatıyla ilgili bu tarihlendirme doğru ise Sakalî̀nin oldukça genç bir yaşta Ebü’l-Arab'dan tahsil görmüş olduğunu düşünebiliriz.

Habîb b. Nasr el-Cezerî̀nin kimliği ise belirsizdir. Bu kişinin, Kuzey Afrika ve Endülüs muhitlerinde Mâlikîliğin yerleşmesinde en önemli paya sahip olan Sahnûn'un (öl. 240/854) öğrencilerinden biri olan Habîb b. Nasr b. Sehl et-Temîmî (öl. 287/900) ) $^{75}$ ile aynı kişi olması muhtemeldir, ancak bu durumda hem tarihsel bakımdan Sakalî’nin ondan ders alması olası değildir, hem de "el-Cezerî" nisbesi bu kişinin farklı biri olabileceğini akla getirmektedir. Ne var ki dönemi ele alan tabakāt eserlerinde bu isimde başka birine rastlanmamaktadır.

Debbâğ'ın Sakalînnin Mekke'de kendisinden ders aldığı isim olarak zikrettiği Ebû Bekir Muhammed b. Hüseyin el-Âcurrî (öl. 360/970) ise bu dönemin tanınmış pek çok âliminin meclisinde ilim tahsil ettiği biri olarak dikkati çeker. Âcurrî'den ders alanlar arasında özellikle dikkati çeken iki isim bulunur: Ebû Tâlib el-Mekkî (öl. 386/996) ve Ebû Nu'aym el-İsfahânî (öl. 430/1038). Bu durum Sakalî’nin bu iki isimle görüşmüş olabileceğini akla getirir. Bilindiği gibi Ebû Tâlib el-Mekkî, Sehl etTüsterî̀yi “İmâmız" diye niteleyen ve Kūtül-kulûb'unda kendisine sayısız atıfta bulunan mutasavvıflardan biridir. Tahsil hayatını büyük ölçüde Mekke'de geçiren Ebû Tâlib'in bu şehre Ebü'l-Hasen Ahmed b. Sâlim'in (öl. 356/967) vefatından önce gelmiş olabileceği belirtilmektedir. ${ }^{76}$ Sakalînnin hac ziyaretini gerçekleştirdiği 350/961 tarihi ve muhtemelen birkaç sene bu bölgede kalmış olduğu hesaba katılacak olursa Ebû Tâlib el-Mekkî ile görüşmüş olması yüksek bir ihtimal olarak değerlendirilebilir. Ancak aynı durum Hilyetü'l-evliyâ müellifi Ebû Nu'aym için zor görünmektedir. Çünkü Ebû Nu'aym'ın ilmî seyahatlerine 356/967 yılında başladığı bilinmektedir. ${ }^{77}$ Kendisinin Âcurrî’den ders aldığı göz önünde bulundurulduğunda, genç yaşta da olsa, hicrî 356-360

\footnotetext{
${ }^{72}$ bk. Ebû Abdirrahman es-Sülemî, Târîhu's-sûfiyye, thk. Muhammed Edîb el-Câdir (Dımaşk: Dâru Nînevâ, 2015).

${ }^{73}$ Debbâğ - İbn Nâcî, Me'âlimü'l-îmân, 3/78-79.

${ }^{74}$ Kādî İyâz, Tertîbü'l-medârik, 6/268-269; Debbâğ - İbn Nâcî, Me âlimü’l-îmân, 3/36-38. Böwering, Ebü'l-Arab'ın vefatını 371/982 olarak belirtir. bk. Böwering, The Mystical Vision, 15; Öngül, “Ebü'l-Arab”, 10/293.

${ }^{75}$ Debbâğ - İbn Nâcî, Méâlimü'l-îmân, 2/198-199.

${ }^{76}$ Saeko Yazaki, Ebû Tâlib el-Mekkîde Tasavvuf, çev. İrfan Kelkitli (İstanbul: Litera Yayınc1lı, 2016), 50-53.

77 Osman Türer, "Ebû Nuaym el-İsfahânî”, Türkiye Diyanet Vakfı İslâm Ansiklopedisi (Ankara: TDV Yayınları, 1994), 10/201-204.
} 
yılları arasındaki bir dönemde Mekke'de bulunduğu tespit edilebilmektedir. Sakalî’nin bu tarihten sonra Mekke'den ayrılmış olması daha muhtemeldir. Dolayısıyla Sakalî’nin Ebû Tâlib el-Mekkî’yi tanıyor olması mümkün iken, Ebû Nu'aym için aynı durum söz konusu edilemez.

\subsubsection{Hicrî Yedinci Asırdan Sonraki Kaynaklarda ve Çağdaş Araştırmalarda Sakalî}

Debbâğ'dan sonra Sakalîye ilk kez Endülüslü ünlü Şâzelî mutasavvıfi İbn Abbâd er-Rundî’nin (öl. 792/1390) mektuplarında rastlanmaktadır. Tasavvufî nasihatleri içeren, müritleri Yahyâ esSerrâc ve Muhammed Edîbe'ye yazılan ve on altı mektuptan oluşan er-Resẩilü's-suğrä’nın sekizinci mektubunda İbn Abbâd, Sakalî̀nin el-Envār'ından uzunca bir pasajı olduğu gibi aktarır. Bu pasajda Sakalî, ilk nesilden başlayarak altı nesil üzerinden Müslümanlarda dinî anlayış ve hassasiyete yönelik bozulmayı anlatır ve çeşitli sınıflandırmalar yapar. İbn Abbâd, Sakalî’nin bu tarih okumasını, daha önce hiçbir âlimin yapamadığı mükemmel bir bakış açısı olarak över. ${ }^{78}$ Dolayısıyla Sakalî, yaklaşık dört asır sonra bile eseri ile tanınan bir mutasavvıf olarak diğer sûfilere, özellikle de Kuzey Afrika ve Endülüs'te yaşayanlara ulaşabilmiştir.

İbn Abbâd'dan başka Debbâğ'dan sonraki müellifler ya Sakalî'den bahsetmemiş ya da ondaki anlatıyı tekrarlamışlardır. Bu çerçevede İbn Ferhûn'un (öl. 799/1397) ed-Dîbâcü̉l-müzheb'inde Sakalî’nin biyografisi yer almazken, Mahlûf (öl. 1941) Şeceretü’n-nûr'da Sakalî için Debbâğ'ın zikrettiği övgü ifadelerini, hadis, fikıh ve usul konusunda uzman olduğu bilgisini yineler, ancak kendisi ve eserleri hakkında başka bilgi vermez. ${ }^{79}$ Brockelmann (öl. 1956) “Ebü'l-Kāsım es-Sakalî”nin Sehl'in sözleri üzerine eş-Şerh ve'l-beyân'ı ve el-Mu'âraża ve'r-red başlıklı eserleri yazdığı bilgisini verir ve vefat tarihini Sem‘ânî̀ye atıfla 423/1032 olarak belirtir..$^{80}$ Ancak bu açıkça hatalıdır, çünkü Sem‘ânînnin bahsettiği Sakalî başka birisidir. ${ }^{81}$ Bağdatlı İsmail Paşa (öl. 1920) ise "es-Sakalî" maddesinde "Abdurrahman b. Muhammed b. Abdillah el-Bekrî es-Sûfî el-Mâlikî"nin 380/990 dolaylarında vefat ettiğini belirtir ve Sehl'e atfedilen yazmalar dışındaki diğer üç eserin ismini zikreder. ${ }^{82}$ Öte taraftan İ̇âhu'l-meknûn'da ise ed-Delāle 'alellāh eserini "el-Envār sahibi Cemâleddîn Abdurrahman es-Sakalî”"ye atfeder, ancak buradaki "Cemâleddîn" isminin "İmâdüddîn" isminin yanlış okunmasından kaynaklanan bir hata olması muhtemeldir. ${ }^{83}$ Kehhâle "Abdurrahman el-Bekrî" adıyla tanıttı̆̆ı Sakalî hakkında Bağdatlı İsmail Paşa'nın verdiği bilgileri aynen tekrarlar. ${ }^{84}$ Ziriklî de "es-Sıkıllı̂” başlığı altında aynı bilgileri tekrar eder. ${ }^{85}$ Fuat Sezgin ise Sehl'in eserlerini incelediği

\footnotetext{
${ }^{78}$ John Renard, Ibn 'Abbād of Ronda: Letters on the Süfï Path, 143-151. İbn Abbâd'in Sakalî’den aktardığı pasaj için bk. Sakalî, el-Envār, 197-198.

${ }^{79}$ Mahlûf, Şeceretü'n-nûr, 1/146.

${ }^{80}$ Brockelmann, GAL, Suppl. 1/333; a. mlf., History of the Arabic Written Tradition, Suppl. 1/336.

${ }^{81}$ Bu sorunun çözümü için bk. Böwering, The Mystical Vision, 13-16.

${ }^{82}$ Bağdatlı İsmail Paşa, Hediyyetü'l-cârifîn, 1/514.

${ }^{83}$ Bağdatlı İsmail Paşa, İżạhu'l-meknûn fi'ż-žeyli 'alâ Keşfi'z-z̧unûn an esâmi'l-kütüb ve'l-fünûn, nşr. Şerafettin Yaltkaya Kilisli Rifat Bilge (İstanbul: Milli Eğitim Basımevi, 1945), 1/476.

${ }^{84}$ Kehhâle, Mu'cemü'l-mü'ellifin, 5/181.

${ }^{85}$ Ziriklî, el-A'lâm, 3/325.
} 
bölümde "Ebü'l-Kāsım Abdurrahman b. Muhammed es-Sakalî’nin" eş-Şerh ve'l-beyân'ı yazdığını belirtir ve Kehhâle'ye atıfla yaklaşık 380/990'da vefat ettiğini söyler. ${ }^{86}$ Öte taraftan Sezgin, Sakalî̀ye ayrı bir başlık açar ve "İmâdüddîn" ismini de ekleyerek el-Envār ve ed-Delāle 'alellāh eserlerinin yazma nüshaları hakkında bilgi verir. ${ }^{87}$

Bu referansların ardından Sakalî, araştırmalarda daha fazla görünmeye başlamıştır. İslâm'ın Sicilya'daki tarihine yönelik araştırmalarıyla bilinen İhsân Abbâs, Sakalî̀yi Sicilya'daki tasavvuf anlayışının en önemli temsilcisi olarak gösterirken, Debbâğ’n Sakalî’nin eserleri hakkında verdiği bilgiye Kitâbün fihh'd-delāletü 'alellāh ve Sehl'in sözleriyle ilgili yukarıda bahsettiğimiz eş-Şerh ve'lbeyân'ı ekler. Abbâs, daha sonra el-Envār'a atıf yaparak Sakalînnin düşünce dünyası hakkında değerlendirmeler yapar. ${ }^{88}$ Mahfûz da bütün bu kaynaklardan hareketle Sakalî’nin derli toplu bir biyografisini vermeye çalışarak onun hakkında ilk kez "el-Kayrevânî" nisbesini kullanmış, vefatını da "yaklaşık 380/990" şeklinde belirtmiştir. ${ }^{89}$

Sehl'e nispet edilen yazma nüshaları yayına hazırlayan Muhammed Kemal Ca'fer de Sakalî’nin bahsi geçen yazmalardaki rolünü ve Sehl'in düşünce dünyasının aktarılmasındaki önemini değerlendirir. Ancak biyografisiyle ilgili verdiği bilgiler hatalıdır. Ona göre Sakalî Sehl'in sözlerini 350/961 yılında Mekke'de bulunduğu esnada öğrenmiş, bu sözleri yorumladığı eş-Şerh ve'lbeyân'1 390/999'da Kayrevân'da yazmışken, Brockelmann gibi o da Sakalî’nin vefat tarihini 423/1032 olarak ifade eder..$^{90}$ Gerhard Böwering, Sehl ile ilgili monografisinde bu yazma nüshalar çerçevesinde Sakalî’nin kimliğindeki belirsizlikleri gidererek kim olduğunu tespit etmeye çalışan ilk araştırmacı olarak görünür. Debbâğ'ın anlatımından hareketle hem onun vefat tarihini “hicrî 386'dan önce, ama 380'den önce kesinlikle değil" diyerek yaklaşık şekilde tespit eder, hem de Sehl'e nispet edilen yazmalardaki Sakalî ile Debbâğ’’n bahsettiği Sakalî’nin aynı kişi olduğunu belirler. Dolayısıyla Sakalî’nin vefatıyla ilgili en çok tercih edilen seçeneğin, “yaklaşık 380/990" olduğu tespit edilmektedir. Ancak Böwering'in Sakalî̀nin görüştüğü kişiler arasında Ebû cikâl'i de sayması -o Ebû 'Ukkâl demektedir- hatalıdır. Çünkü Ebû cỉkâl, Debbâğ’ın Sakalî’nin eserinden aktardığı ve yukarıda tercümesini verdiğimiz pasajda başka biriyle irtibat halindedir ve Sakalînnin tarihsel olarak

\footnotetext{
${ }^{86}$ Sezgin, GAS, 1/647; a.mlf., Arap-İslâm Bilimleri Tarihi, 1/744.

${ }^{87}$ Sezgin, GAS, 1/666; a.mlf., Arap-İslâm Bilimleri Tarihi, 1/766.

${ }^{88}$ İhsân Abbâs, el-Arab fî Stkılliye: Dirâse fi't-târîh ve'l-edeb (Kahire: Dâru'l-Ma'ârif, 1959), 112-119. Burada Sakalînnin Sicilya'daki en önemli tasavvuf temsilcisi olarak gösterilmesine ihtiyatlı yaklaşmak gerekir, çünkü Sakalînnin Sicilya'da ne kadar yaşadığı bilinmemektedir. Sakalî hakkında benzer bir değerlendirme yapan başka bir kaynak için bk. Abdüsselâm Ġarmînî, el-Medârisu's-sûfiyyeti'l-Mağrîbiyye ve'l-Endelusiyye fî karni's-sâdisi'l-hicrî (Casablanca: Dâru'r-Reşâd el-Hadîse, 2000), 42.

${ }^{89}$ Mahfûz, Terâcimü'l-müellifin, 1/114-115.

${ }^{90}$ Ca'fer, "Temhîd ve Dirâse", 58-60. Bu arada Ca‘fer, Sakalînnin el-Envār'ının başka bir isminin Cevâhirü'l-elfâz ve zuhûru'l-envâr olduğunu kaydeder (s. 53).
} 
291/903'de Mekke'de vefat eden Ebû 'íkâl ile görüşmüş olması olası değildir. ${ }^{91}$ Bununla birlikte Böwering, Tüsterînnin görüşlerini incelerken Sakalî’nin yorumlarına sık sık atıfta bulunur. ${ }^{92}$ Şimdi bütün bu bilgilerden hareketle ilgili kaynaklara yeniden atıf yapmadan Sakalî̀nin biyografisine dair güncel bir anlatı oluşturmaya çalışacağız.

\section{Sonuç ya da Bir Biyografi Denemesi: Ebü'l-Kāsım es-Sakalî Kimdir?}

Tam adı Ebü'l-Kāsım ‘İmâdüddîn Abdurrahman b. Muhammed b. Abdillah el-Bekrî el-Mâlikî es-Sakalî (bazı kaynaklarda es-Sakallî veya es-Sıkıllî) el-Kayrevânî olan müellifin doğum tarihi tam olarak bilinmemektedir. Ancak 4./10. yüzyılın hemen başında Sicilya'da dünyaya geldiği ve ilk gençlik döneminin ardından dinî ilimleri tahsil etmek amacıyla Kayrevân'a geçtiği tahmin edilebilir. Sakalî, Kayrevân'da dönemin önde gelen Mâlikî âlimlerinden hadis, fikıh ve usûl-i fikıh tahsil etti. Ders aldığı hocalar arasında Ebü’l-Arab et-Temîmî (öl. 333/945), Ebû İshâk es-Sebâî' (öl. 356/967), Ebü'l-Hasen Ali b. Muhammed b. Mesrûr ed-Debbâğ (öl. 359/970), Ebü'l-Kāsım Ziyâd b. Yûnus (öl. 361/972), Ebû Mâlik Sa‘d b. Mâlik b. 'Ubbâde ed-Debbâğ (öl. 361/972) ve Habîb b. Nasr el-Cezerî (öl. [?]) öne çıkmaktadır.

Dinî ilimleri tahsil ettiği esnada Kayrevân'a çok yakın bir liman kenti olan Münestîr'de "velî bir zât" olarak tanınan Ebü'l-Fazl el-Abbâs b. Muhammed es-Savvâf el-Ġadâmisî (öl. 349/961) ile görüştü. 350/961 yılında hac vazifesini yerine getirmek üzere Hicaz'a gitti. Bu seyahati sırasında Ebû Abdillah Muhammed b. Ahmed b. İbrâhîm el-Belhî, Ebü'l-Hasen Ali b. Ahmed b. Zekeriyyâ el-Hâşimî, Ali b. Hüseyin b. Findâr el-Kādî ve Ebû Bekir b. Atîk b. Mûsâ b. Hârûn el-Hâtemî gibi âlimlerle görüşme firsatı buldu. Mekke'deyken ünlü âlim Ebû Bekir Muhammed b. Hüseyin el-Âcurrî̀den (öl. 360/970) ders aldı. Bu eğitimi sırasında muhtemelen Ebû Tâlib el-Mekkî (öl. 386/996) ile görüşme imkânı buldu. Aynı zamanda Bağdat ve Basra çevresinde tekâmülünü tamamlayan tasavvuf anlayışlarını yakından tanıma firsatı buldu ve Sehl b. Abdillah et-Tüsterînin (öl. 283/896) talebeleriyle irtibat kurdu. Bu kapsamda bir tasavvuf ve kelam firkası olan Sâlimiyye'nin kurucularından Ebü'l-Hasen Ahmed b. Sâlim'in (öl. 356/967) yakın talebesi Muhammed b. Abdillah

\footnotetext{
${ }^{91}$ Böwering, The Mystical Vision, 13-16. Ebû cỉkâl, Sakalî’nin ilim tahsil ettiği isimlerden biri olan Ebû Bekir b. Sa 'dûn'un üstadı olarak geçer. Gençliğinde önemli bir siyasi mevkiye sahipken tevbe edip tasavvuf yoluna girmiş, Kayrevân'dan ayrılmış ve hayatının büyük kısmını hocası Ebû Hârun el-Endelûsî ile beraber Mekke'de geçirmiş ve orada vefat etmiştir. Ebû cikâl (öl. 291/903) ve hocası Ebû Hârun el-Endelûsî (öl. 291/903) hakkında ayrıntılı bilgi için bk. Ebû Bekir el-Mâlikî, Riyâżü’n-nüfûs, 1/516-526, 528-545; Ebû Bekir Muhammed b. Velîd et-Turtûşî, Sirâcü’lmülûk, thk. Muhammed Fethi Ebû Bekir (Kahire: ed-Dâru'l-Misriyyetü'l-Lübnâniyye, 1414/1994), 1/84-86; Debbâğ - İbn Nâcî, Me âlimü'l-îmân, 2/214-232. Ebû cìkâl erken dönem tasavvuf klasiklerinde ise neredeyse hiç yer almaz. Bulabildiğim tek örnek Kuşeyrînnin vecd ve tevâcüd bağlamında Sülemî’den aktardığı bir rivayette geçer. bk. Kuşeyrî, er-Risâletü'l-Kuşeyriyye, 143; a.mlf., Kuşeyrî Risâlesi, 157; Süleyman Uludağ, "Behlûl-i Dânâ", Türkiye Diyanet Vakfi İslâm Ansiklopedisi (Ankara: TDV Yayınları, 1992), 5/352-353.

${ }^{92}$ Aynı bağlamda eklememiz gereken son çalışma ise, Sakalî̀nin -çalışmada Sicillî olarak isimlendirilir- Sehl'in sözlerine ilişkin çok sayıda yorumunu değerlendiren Fatma Gedik'in çalışmasıdır. bk. Fatma Gedik, Sehl b. Abdullah et-Tüsterîve Tasavvufi Görüşleri (Ankara: Ankara Üniversitesi, Sosyal Bilimler Enstitüsü, Doktora Tezi, 2019).
} 
en-Nihâvendî'den (öl. [?]), Sehl'in pek çok sözünü tahdis etti. Mekke ve Medine'de bulunduğu ylllarda Cüneyd-i Bağdâdî̀nin (öl. 297/909) talebeleriyle de irtibat kuran Sakalî, Muhammed b. Ali eş-Şînâzî vasıtasıyla İbn Hafîf eş-Şî̂â̂înin (öl. 371/982) de görüşlerini tanıma imkânı buldu. Muhtemelen birkaç sene süren Mekke ve Medine döneminden sonra Kayrevân'a tekrar dönen Sakalî, bu esnada Mısır'a uğradı ve başta Nifferî (öl. 354/965’ten sonra) olmak üzere çeşitli mutasavviflarla görüştü.

Kayrevân'a döndükten sonra Sehl et-Tüsterînnin bir takipçisi olarak, kalabalık bir talebe grubuna dinî ilimleri öğretmeye ve muhtemelen "bir tarikat şeyhi" olarak irşad vazifesi yürütmeye başladı. Mekke ve Medine'de derlediği Sehl'in sözlerinin büyük bir kısmını Kitâbu'ş-Şerh ve'l-beyân li mâ eşkele min kelâmî Sehl başlığında bir risale yazarak şerh etti. Aynı zamanda Sehl'e nispet edilen Kitâbu'l-Mu'âraża ve'r-red 'alâ ehli'l-firakve ehli'd-da'âvâ fi'l-ahvvâl' ïğrencilerine okuttu ve bu eserin de büyük bir kısmını şerh etti. Zaman içinde telif faaliyetlerine hız kazandırdı ve "Envāru's-Sakalî" olarak da bilinen meşhur eseri el-Envār fî 'ilmi'l-esrār ve makāmāti'l-ebrār'1 ve ed-Delāle 'alellāh başlıklı eserini yazdı. Sakalî̀nin aynı zamanda günümüze ulaşmayan Șlfatü'l-evliy $\bar{a}^{’} v e$ merātibu aḥvāli'l-asfiyā' ile Kerāmātü'l-evliyā' ve'l-muți îne mine's-sahābe ve't-tābi īne ve men tebi'ahum bi ihsān başlıklı eserlerin müellifi olduğu belirtilmektedir. Bu eserlerde ilmî ve dinî hayatta döneminde şahit olduğu bozulmalara sert tepki gösterdi ve eleștirilerinde ilim ve amel bütünlügüne özen göstermeyen âlimleri hedef aldı. Aynı zamanda tasavvufun en önemli konularından velâyet ve kerâmetlere dair görüşlerini belirtti.

Hayatının son döneminde velâyet ve kerâmetlere dair görüşleri nedeniyle, Kayrevân'da kendisiyle aynı ilim çevresinde yetişen ünlü Mâlikîâlimler İbn Ebû Zeyd (öl. 386/996) ve Ebü'l-Hasen el-Kābisî (öl. 403/1012) ile ihtilaf yaşadı. Her iki âlim de yazdıkları reddiyeler ile Sakalînnin görüşlerine karşı çıktılar. Kayrevân'daki bu ihtilaf kısa sürede Mekke, Bağdat ve Endülüs bölgesindeki âlimlerin de dâhil olduğu büyük bir tartışmaya dönüştü, ancak aralarında ünlü MâlikîEş‘arî kelamcısı Bâkıllânî’nin (öl. 403/1013) de olduğu âlimlerin büyük çoğunluğu Sakalî̀nin görüşlerini destekledi. Ebü'l-Kāsım es-Sakalî’nin ne zaman vefat ettiği tam olarak bilinmemektedir. 380/990, 382/992 ve 423/1032 tarihleri öne çıkmakla birlikte kaynakların büyük çoğunluğu onun 380/990'dan hemen sonra vefat etmiş olabileceğini kabul etmektedir.

2. ve 5./8. ve 11. yüzyıllar arasındaki dönem, tasavvufun bir ahlâk hareketi olarak gelişim gösterip zaman içinde "dinî ilim" hüviyeti kazandığı bir süreci ifade eder. Tasavvufun bu dönüşümü yaşamasında, Irak ve Horasan havzalarındaki entelektüel ve sosyo-kültürel gelişmeler özellikle etkili olmuş ve erken dönem tasavvuf literatürünün önemli bir kısmı da bu muhitlerde kaleme alınmıştır. Bununla birlikte Ebü'l-Kāsım es-Sakalî’nin biyografisini ortaya koymayı amaçladığımız bu çalışma, 4./10. yüzyılda Kayrevân merkezde olmak üzere Kuzey Afrika havzasında da aynı sürecin yaşandığını; tasavvufun kimlik kazanmasında kilit role sahip "şeriat-hakikat" tartışmalarının tezahür ettiği velâyet ve kerâmet konularına dair ihtilafların bu bölgede etkili ve yaygın bir şekilde yaşandığını ve nihayet bu tartışmalarda Sakalînnin öncü bir isim olarak dikkati çektiğini göstermektedir. Sakalî’nin hem Sehl et-Tüsterî ve Cüneyd-i Bağdâdî etkisinde gelişen tasavvuf 
ekolleriyle irtibatı hem de Kayrevân'da Mâlikîliğin yerleşmesini temin eden âlimlerle olan bağlantısı, onun bu iki zümrenin duyarlılıklarını aynı anda dikkate alan bütünleştirici bir bakış açısına sahip olmasını temin etmiştir. Bu bakımdan Sakalî’nin tasavvufun Kuzey Afrika'da gösterdiği gelişim seyrindeki etkisi daha fazla araştırmayı hak etmekte, bilhassa el-Envār ve ed-Delāle 'alellāh başlıklı eserlerinin bu bağlamda incelenmesi büyük önem arz etmektedir.

\section{Kaynakça}

Abbâs, İhsân. el-Arab fí Sikılliye: Dirâse fi't-târîh ve'l-edeb. Kahire: Dâru'l-Ma'ârif, 1959.

Alkan, Ercan. Şerhu Hal'i'n-Na'leyn: Hal'u'n-Na'leyn Şerhi. İstanbul: Türkiye Yazma Eserler Kurumu Başkanlığı Yayınları, 2017.

Amari, Michele. Storia dei Musulmani di Sicilia. 3 Cilt. Firenze: Felice Le Monnier, 1854-1868.

Bağdatlı İsmail Paşa. İzâhhu'l-meknûn fi'z-žeyli 'alâ Keşfi'z-zunûn an esâmi'l-kütüb ve'l-fünûn. nşr. Şerafettin Yaltkaya - Kilisli Rifat Bilge. 2 Cilt. İstanbul: Milli Eğitim Basımevi, 1945.

Bağdatlı İsmail Paşa. Hediyyetü'l-cârifin, esmâ'ü'l-müellifin ve âsârü'l-musannifin. nşr. Kilisli Rifat Bilge İbnülemin Mahmûd Kemal İnal. 2 Cilt. İstanbul: Milli Eğitim Basımevi: 1951.

Başer, Hacı Bayram. Şeriat ve Hakikat: Tasavvufun Teşekkül Süreci. İstanbul: Klasik Yayınları, 2017.

Bekkûş, Beşîr. "Mukaddime”. Riyâzü̈n-nüfûs. mlf. Ebû Bekir Abdullah b. Muhammed el-Mâlikî. 1/1332. Beyrut: Dâru'l-Garbi'l-i̇slâmî, 1414/1994.

Böwering, Gerhard. The Mystical Vision Existence in Classical Islam: Qur'änic Hermeneutics of the Șüfi Sahl At-Tustarì (d. 283/896). Berlin: De Gruyter, 1980.

Böwering, Gerhard. "Zulme Uğrayan ve İlhâdla Suçlanan İlk Sufîler”. çev. Abdurrezzak Tek. Uludă̆ Üniversitesi İlahiyat Fakültesi Dergisi 12/2 (2003), 361-384.

Brockelmann, Carl. Geschichte der arabischen Litteratur. 5 Cilt. Leiden: Brill, 1937-1949.

Brockelmann, Carl. History of the Arabic Written Tradition. çev. Joep Lameer. 5 Cilt. Leiden: Brill, 2016.

Brown, Jonathan. The Canonization of al-Bukhāri and Muslim: The Formation and Function of the Sunnī Hadith Canon. Leiden, Boston: Brill, 2007.

Ca'fer, Muhammed Kemal İbrâhim. "Temhîd ve Dirâse". el-Mu'âraża ve'r-red 'alâ ehli'l-firak ve ehli'dde $\hat{a} v a ̂$ fi'l-aḥvâl. mlf. Sehl b. Abdullah et-Tüsterî. 7-69. Kahire: Dâru'l-İnsân, 1980.

Câmî, Abdurrahman. Evliyâ Menkıbeleri: Nefahâtül-Üns. çev. Lâmiî Çelebi. nşr. Süleyman Uludağ Mustafa Kara. İstanbul: Pinhan Yayınc1lı, 2011.

Çakmaklığlu, M. Mustafa. Hakikat Yolcusunun Son Durağı: Abdülcebbâr en-Nifferîye Göre Vakfe. İstanbul: Litera Yayınc1lık, 2016.

Debbâğ, Abdurrahman b. Muhammed - İbn Nâcî et-Tenûhî. Me'âlimü'l-îmân fí ma'rifeti ehli'l-Kayrevân. nşr. Muhammed el-Ahmedî Ebü'n-Nûr - Muhammed Mâdûr. 3 Cilt. Kahire: Mektebetü'lHancî - Tunis: Mektebetü'l-Atîka, 1968-1978.

Demirli, Ekrem. "Nifferî”. Türkiye Diyanet Vakfi İslâm Ansiklopedisi. 33/81-82. Ankara: TDV Yayınları, 2007. 
Ess, Josef van. Theology and Society in the Second and Third Century of the Hijra. çev. John O'Kane Gwendolin Goldbloom. 4 Cilt. Leiden: Brill, 2017-2019.

Ezdî, Abdülganî. el-Mü’telif ve'l-muhtelif fî esmẩi'r-ricâl. thk. Müsnâ Hamîd eş-Şemerî - Kays Abdu İsmail et-Temîmî. Beyrut: Dâru'l-Garbi'l-i̇slâmî, 1428/2007.

Fierro, Maribel. "The Polemic about the "karāmāt al-awliyā" and the Development of Șūfism in alAndalus (Fourth/Tenth-Fifth/Eleventh Centuries)". Bulletin of the School of Oriental and African Studies 55/2 (1992), 236-249.

Fierro, Maribel. "Endülüs'te Tasavvufa Muhâlefet = Opposition to Sufism in al-Andalus”. çev. Semih Ceyhan. Uludağ Üniversitesi İlahiyat Fakültesi Dergisi 18/2 (2009), 327-359.

Fîrûzâbâdî, Ebü't-Tâhir Mecdüddîn. el-Kāmmûsü'l-muhîț. Beyrut: Müessesetü'r-Risâle, 1426/2005.

Ġarmînî, Abdüsselâm. el-Medârisu's-sûfiyyeti'l-Mağrîbiyye ve'l-Endelusiyye fi karni's-sâdisi'l-hicrî. Casablanca: Dâru'r-Reşâd el-Hadîse, 2000.

Gedik, Fatma. Sehl b. Abdullah et-Tüsterî ve Tasavvufî Görüşleri. Ankara: Ankara Üniversitesi, Sosyal Bilimler Enstitüsü, Doktora Tezi, 2019.

Hanefî, Hasan. Mine'l-fenā ile'l-bekā. 2 Cilt. Beyrut: Dâru'l-Medâri'l-İslâmî, 2009.

İbn Ferhûn, Burhâneddin. ed-Dîbâcü'l-müzheb fì ma'rifeti a'yâni 'ulemầi'l-mezheb. thk. Muhammed elAhmedî Ebü'n-Nûr. 2 Cilt. Kahire: Dâru't-Türâs, 1972.

İbn Hallikân, Ebü'l-Abbâs Şemsüddîn. Vefeyâtü'l-a'yân ve enbâ'ü ebnẩ' 'z-zamân. nşr. İhsan Abbas. 8 Cilt. Beyrut: Dâru Sâdır, 1968-1972.

İbn Hurdâzbih, Ebü'l-Kāsım Ubeydullāh. Kitâbü'l-Mesâlik ve'l-memâlik. nşr. Michael Jan de Goeje. Leiden: Brill, 1889.

Kādî İyâz, Ebü'l-Fazl İyâz b. Mûsâ. Tertîbül-medârik ve takrî̉bü'l-mesâlik li-ma'rifeti a'lâmi mezhhebi Mâlik. thk. Muhammed b. Tâvît et-Tancî v.dğr. 8 Cilt. Rabat: Vizâretü'l-Evkâf ve'ş-Şuûni'lİslâmiyye, 1981.

Kara, Mustafa. "Ca'fer el-Huldî". Türkiye Diyanet Vakfi İslâm Ansiklopedisi. 6/551. Ankara: TDV Yayınları, 1992.

Karapınar, Fikret. Muhaddis Sufilerin Hadis Usulü ve Hadisi Anlama Yöntemleri (H. IV-V./M. X-XI. Astr). Konya: Selçuk Üniversitesi, Sosyal Bilimler Enstitüsü, Doktora Tezi, 2006.

Kartal, Abdullah. Tasavvufun Oluşumu: Şeriat-Hakikat İlişkisi. Bursa: Emin Yayınları, 2015.

Kehhâle, Ömer Rızâ. Mu'cemü'l-mü’ellifîn. 15 Cilt. Beyrut: Mektebetü'l-Müsennâ, 1957.

Kehhâle, Ömer Rızâ. Mu'cemü'l-mü’ellifinn. 4 Cilt. Beyrut: Müessesetü'r-Risâle, 1993.

Knysh, Alexander. Sufism: A New History of Islamic Mysticism. Princeton: Princeton University Press, 2017.

Kuşeyrî, Abdülkerîm. er-Risâletü'l-Kuşeyriyye. nşr. Abdülhalîm Mahmûd - Mahmûd b. Şerîf. Kahire: Metâbi'u Müessesetu'd-Dâru'ş-Şa'b, 1989.

Kuşeyrî, Abdülkerîm. Tasavvuf Illmine Dair Kuşeyrî Risâlesi. çev. Süleyman Uludağ. İstanbul: Dergâh Yayınları, 2014. 
Mahfûz, Muhammed. Terâcimü'l-müellifine't-Tûnisiyyîn. 5 Cilt. Beyrut: Dâru'l-Garbi'l-İslâmî, 14021406/1982-1986.

Mahlûf, Muhammed. Şeceretü'n-nûri'z-zekiyye fî țabakāti'l-Mâlikiyye. thk. Abdülmecîd Hayâlî. 2 Cilt. Beyrut: Dâru'l-Kütübi'l-İlmiyye, 1424/2003.

Mâlikî, Ebû Bekir Abdullah b. Muhammed. Riyâzü̈’n-nüfûs. thk. Beşîr Bekkûş. 2 Cilt. Beyrut: Dâru'lGarbi'l-İslâmî, 1414/1994.

Massignon, Louis. Essai sur les Origines de Lexique Technique de la Mystique Musulmane. Paris: Paul Geuthner, 1922.

Massignon, Louis. Essay on the Origins of the Technical Language of Islamic Mysticism. çev. Benjamin Clark. Notre Dame, Indiana: University of Notre Dame Press, 1997.

Massignon, Louis. Kitâb al-Ṭawâsîn. Paris: Paul Geuthner, 1913.

Mütercim Âsım Efendi. el-Okyânûsü'l-basit fî tercemeti'l-Kāmûsi'l-muhît: Kâmûs Tercümesi. nşr. Mustafa Koç - Eyyüp Tanrıverdi. 6 Cilt. İstanbul: Türkiye Yazma Eserler Kurumu Başkanlığı, 2013.

Nemerî, İbn Abdülber. el-Kașd ve'l-ümem fi't-ta'rîf bi-uṣ̂uli ensâbi'l-'Arab; el-İnbâh 'alâ kabâ'ili'r-ruvât. Kahire: Mektebetü'l-Kudsî, ts.

Nifferî, Abdülcebbâr. Mevâkıf. nşr. Nurullah Koltaş - Orkhan Musakhanov. İstanbul: Büyüyenay Yayınları, 2017.

Öngül, Ali. “Ebü'l-Arab”. Türkiye Diyanet Vakfi İslâm Ansiklopedisi. 10/293. Ankara: TDV Yayınları, 1994.

Özköse, Kadir. Afrika Tasavvuf Araştırmaları. Trabzon: Kalem Yayınevi, 2019.

Özköse, Kadir. Endülüs ve Afrika'da Tasavvuf Kültürü. Trabzon: Kalem Yayınevi, 2019.

Ramli, Harith Bin. "The Sālimiyya and Abū Țālib al-Makkī: The Transmission of Theological Teachings in a Basran circle of mystics". Les maîtres soufis et leurs disciples des III ${ }^{e}-V^{e}$ siècles de l'hégire $\left(I X^{e}-X I^{e}\right)$ : Enseignement, formation et transmission. ed. Geneviève Gobillot \& Jean-Jacques Thibon. 101-129. Damas-Beyrouth: Presses de l'Ifpo, 2012.

Reinert, Benedikt. Die Lehre vom Tawakkul in der Klassischen Sufik. Berlin: De Gruyter, 1968.

Renard, John. Ibn 'Abbād of Ronda: Letters on the Süfi Path. New York: Paulist Press, 1986.

Sakalî, Ebü'l-Kāsım Abdurrahman b. Muhammed. Kitâbu'ş-şerh ve'l-beyân li mâ eşkele min kelâmî Sehl. İstanbul: Süleymaniye Kütüphanesi, Köprülü, 727, 154a-206a.

Sakalî, Ebü'l-Kāsım Abdurrahman b. Muhammed. Kitâbu'ş-şerh ve'l-beyân li mâ eşkele min kelâmî Sehl. İstanbul: Süleymaniye Kütüphanesi, Esad Efendi, 1623, 1a-42a.

Sakalî, Ebü'l-Kāsım Abdurrahman b. Muhammed. el-Envār fì 'ilmi'l-esrār ve makāmāti'l-ebrār. thk. Ahmed Ferîd el-Mezîdî. Beyrut: Dâru'l-Kütübi'l-İlmiyye, 1421/2000.

Sakalî, Ebü'l-Kāsım Abdurrahman b. Muhammed. ed-Delāle 'alellāh. thk. Ahmed Ferîd el-Mezîlî. Beyrut: Dâru'l-Kütübi'l-İlmiyye, 1422/2001.

Sem‘ânî, Abdülkerîm b. Muhammed. el-Ensâb. nşr. Abdullah Ömer el-Bârûdî. 5 Cilt. Beyrut: Dâru'lCinân, 1408/1988.

Sezgin, Fuat. Geschichte des arabischen Schrifttums. 17 Cilt. Leiden: Brill, 1967-2015. 
Başer, Ebü'l-Kāsım Abdurrahman es-Sakalî (ö. 380/990 [?]) ve Tasavvuf Tarihindeki Yeri

Sezgin, Fuat. Târîhu't-türâsi'l-Arabî. çev. Mahmûd Fevzî Hicâzî. 8 Cilt. Riyad: Câmiatü'l-İmâm Muhammed b. Suud el-İslâmiyye, 1403/1983.

Sezgin, Fuat. Arap-İslâm Bilimleri Tarihi. İstanbul: Prof. Dr. Fuat Sezgin İslam Bilim Tarihi Araştırmaları Vakfı, 2015.

Sobieroj, Florian. Ibn-Ḥafif aš-Šì̄āzì und seine Schrift zur Novizenerziehung (Kitāb al-iqtișād). Beyrut: Franz Steiner Verlag, 1988.

Steingass, Francis Joseph. Persian-English Dictionary. London: Routledge \& Kegan Paul, 1963.

Sülemî, Ebû Abdirrahman. Târîhu's-sûfiyye. thk. Muhammed Edîb el-Câdir. Dımaşk: Dâru Nînevâ, 2015.

Tunç, Cihat. Sahl b. 'Abdallāh at-Tustarī und die Sālimìya Übersetzung und Erläuterung des Kitāb almu ārada. Bonn: Rheinische Friedrich-Wilhelms-Universität, Doktora Tezi, 1970.

Tunç, Cihat. "Sâlimiyye”. Türkiye Diyanet Vakfi İslâm Ansiklopedisi. 36/50-51. Ankara: TDV Yayınları, 2009.

Turtûşî, Ebû Bekir Muhammed b. Velîd. Sirâcü'l-mülûk. thk. Muhammed Fethi Ebû Bekir. 2 Cilt. Kahire: ed-Dâru'l-Mısriyyetü'l-Lübnâniyye, 1414/1994.

Türer, Osman. "Ebû Nuaym el-İsfahânî”. Türkiye Diyanet Vakfi İslâm Ansiklopedisi. 10/201-204. Ankara: TDV Yayınları, 1994.

Tüsterî, Sehl b. Abdillah. Kitâbu'l-Mu'âraża ve'r-red 'alâ ehli'l-firak ve ehli'd-da'âvâ fi'l-ahvâll. İstanbul: Süleymaniye Kütüphanesi, Köprülü, 727, 206a-243b.

Tüsterî, Sehl b. Abdillah. el-Mu'âraża ve'r-red 'alâ ehli'l-firak ve ehli'd-da'âvâ fi'l-aḥvâl. thk. Muhammed Kemal İbrâhim Ca'fer. Kahire: Dâru'l-İnsân, 1980.

Uludağ, Süleyman. "Behlûl-i Dânâ". Türkiye Diyanet Vakfi İslâm Ansiklopedisi. 5/352-353. Ankara: TDV Yayınları, 1992.

Venşerî̀î. el-Micyârrü'l-mu'rib ve'l-câmi'u'l-muğrib 'an fetâvâ 'ulemâ’i Iffrîkıyye ve'l-Endelüs ve'l-Maġrib. nşr. Muhammed Hacî. 13 Cilt. Rabat: Vizâretü'l-Evkâf - Beyrut: Dâru'l-Garbi'l-İslâmî, 1401/1981.

Yâkūt el-Hamevî. Mu'cemü'l-büldân. 5. Cilt. Beyrut: Dâru Sâdır, 1397/1993.

Yazaki, Saeko. Ebû Tâlib el-Mekkîde Tasavvuf. çev. İrfan Kelkitli. İstanbul: Litera Yayıncılık, 2016.

Ziriklî, Hayreddin. el-A'lâm: Kāmûsü terâcim. nşr. Züheyr Fethullah. 8 Cilt. Beyrut: Dâru'l-İlm li'lMelâyîn, 2002. 


\section{Abū al-Ḳāsim ‘Abd al-Raḥmān al-Ṣaqalī (d. 380/990 [?]) and His Place in the History of Șūfism}

\section{Dr. Hacı Bayram BAŞER}

\section{Extended Summary}

The prevalence of Șūfism in early Islāmic society is one of the crucial problems of contemporary research. It can be said that the course of the discussions about this process, which spread until the fifth/eleventh century, was primarly determined by the Șūfĩs living in the region of Irāq and Khorasān and their works. This is a problem that makes it difficult to discuss the development process of Șūfism in different parts of the Islāmic world such as al-Andalus, Maghrib, and Ifriqiya with the same depth. Therefore, one of the ways to overcome this problem may be to focus on the Șuffis who were influential in milieus in the early period. One of the names that should be addressed in this manner is Abū al-Ḳāsim 'Abd al-Rahmān al-Ṣaqalī (d. 380/990 [?]). Șaqalī is a Șūfĩ who was born in Sicily and grew up in the scientific environment in which Mālikī scholars existed in al-Qayrawān. Although he spent most of his life in al-Qayrawān, his travels to the eastern region of the Islāmic world and the Șufiss that he contacted during this time were effective in forming his views on Șūfism. In this context, Șaqalī, as one of the followers of the famous Șūfĩ master Sahl b. 'Abdallāh al-Tustarī (d. 283/896), penned his works such as Kitāb al-sharh wa-l-bayān li mā ashkala min kalāmī Sahl, al-Anwār fì 'ilm al-asrār wa makāmāt al-abrār and al-Dalāla 'alā Allāh in which he both explained Sahl's words and reflected his own understanding of Șūfism. He discussed the issues of wilāya and karāmāt with the Mâlikī scholars of this period, and these discussions had an echo in different parts of the Islāmic world which led to the formation of a literature. However, the primary problem with Șaqali is that there is a lot of uncertainty in what we know about his biography. In this article, it is aimed to reach an up-to-date and accurate narrative of Șaqalī's biography by examining the information in the classical and contemporary literature in a comparative manner and eliminating the aforementioned ambiguities. The first uncertainty about Șaqalî is about how to read his nisba (agnomen). In this framework, it is determined that this nisba, which means "Sicilian", is read as "al-Ṣaqalī", "al-Ṣaqallī" and "al-Ṣikillī” in the classical and contemporary literature. Among these, it is claimed that the reading in the form of "al-Ṣaqalī" is preferred in terms of ensuring continuity in the literature in terms of both the information given by Samcānì (d. $562 / 1166)$, the author of $a l-A n s \bar{a} b$, and the preferences in the contemporary literature.

Throughout the article, a chronological follow-up of classical and contemporary sources is made to reveal Șaqalì's biography. In this context, it is pointed out that the chains of narration in some manuscripts attributed to Sahl give the details of Șaqali's travel to the east, it is claimed that he established an indirect contact with one of the leading students of Sahl and one of the founders of Sālimiyya, a theological-mystical school, Abū al-Ḥasan Aḥmad b. Sālim (d. 356/967) in 350/961 when Șaqalì made his pilgrimage. In this context, the role of Muhammad b. 'Abdallāh al-Nihāwandī 
in Șaqalī’s relationship with Sālimiyya is emphasized. Also, it is determined that Șaqalī met with names such as Abū Nașr al-Baladī, Abū Bakr al-Khorasānī, Abū Bakr al-Zakkāk and recognized the mysticism around Baghdad and Basra. It is determined that Șaqalī also met with Muhammad b. 'Alī al-Shīrāzī, the student of the famous Ṣūfĩ Ibn Hafîf al-Shīrāzī (d. 371/982), and it is revealed that he met with Niffārī (d. 354/965) in Egypt in person. Niffārī stood out as an idiosyncratic in the history of Șūfism and there is uncertainty about the people he was in contact with.

It is claimed that the information about the life of Șaqali in and around al-Qayrawān is not included in Șūfi works, but in Mālikī țabaqāt literature. Within this framework, Abū Bakr al-Mālikī's (d. 494/1100 [?]) Riyāẹ al-nufūs, al-Qāḍi 'Iyāḍ's (d. 544/1149) Tartīb al-madārik and al-Dabbāgh's (d. 699/1300) Ma'ālim al-imān are analyzed comparatively. It is determined that the narrative in these works largely determined what we know about Șaqalī's biography. According to this, Șaqalī completed his first education in al-Qayrawān in the hands of the leading Mālikī scholars of the period such as Abū al-'Arab al-Tamīmī (d. 333/945), Abū Ishāa al-Sabāī (d. 356/967) and Abū al-Ḥasan al-Dabbāgh (d. 359/970), then turned to Șufism, and he was in contact with many șūfis, especially Abū al-Faḍl al-Ghadāmisī (d. 349/961). The article also evaluates information about both the scholars with whom Șaqali studied religious sciences and the Șüfis with whom he may be in contact with. After returning from hajj to al-Qayrawān Șaqalī's argument upon with prominent Mālikī scholars Ibn Abī Zayd (d. 386/996) and Abū al-Ḥasan al-Qābisī (d. 403/1012) on wilāya and karāmāt is also mentioned in the article. In this respect, this conflict in al-Qayrawān soon turned into a great debate involving scholars in Mecca, Baghdad, and Andalusia, but most of the scholars, including the famous Mālikī-Ash`arī theologian Bāqillānī (d. 403/1013) who supported Șaqalī’s views and the traces of this debate are mentioned in the Māliki figh literature. Finally, the information about the date of death of Abū al-Kāsim al-Ṣaqalī is discussed and it is seen that he may have died right after $380 / 990$.

The period between the second and fifth centuries AH, when Șūfism developed as a moral movement and became "religious science" over time, is not just a transformation that took place in the Irāq and Khorasān regions. This process was similarly experienced in North Africa, and Abū alKāsim al-Ṣaqali became one of the leading names of Șüfism in this milieu. His connection with the Irāqī Șūfis and the works he left behind require more attention in contemporary șufism studies.

Keywords: Șūfism, al-Ṣaqalī, al-Ṣaqallī, al-Ṣiḳillī, Sahl al-Tustarī, Ibn Abī Zayd, Wilāya, Karāmāt. 
